\title{
Water, Waste Material, and Energy as Key Dimensions of Sustainable Management of Early Childhood Eco-Schools: An Environmental Literacy Model Based on Teachers Action-Competencies (ELTAC)
}

\author{
Abigail López-Alcarria, María Fátima Poza-Vilches*(D), María Teresa Pozo-Llorente (D) and José Gutiérrez-Pérez (D) \\ Educational Methodology Research Department, Faculty of Education, University of Granada, 10871 Granada, \\ Spain; abigail@ugr.es (A.L.-A.); mtpozo@ugr.es (M.T.P.-L.); jguti@ugr.es (J.G.-P.) \\ * Correspondence: fatimapoza@ugr.es
}

Citation: López-Alcarria, A.; Poza-Vilches, M.F.; Pozo-Llorente, M.T.; Gutiérrez-Pérez, J. Water, Waste Material, and Energy as Key

Dimensions of Sustainable Management of Early Childhood Eco-Schools: An Environmental Literacy Model Based on Teachers Action-Competencies (ELTAC). Water 2021, 13, 145. https://doi.org/ 10.3390/w13020145

Received: 27 November 2020 Accepted: 7 January 2021 Published: 10 January 2021

Publisher's Note: MDPI stays neutral with regard to jurisdictional clai$\mathrm{ms}$ in published maps and institutional affiliations.

Copyright: (C) 2021 by the authors. Licensee MDPI, Basel, Switzerland. This article is an open access article distributed under the terms and conditions of the Creative Commons Attribution (CC BY) license (https:// creativecommons.org/licenses/by/ $4.0 /)$.

\begin{abstract}
The main argument defended in this article is that the involvement of teachers in decisionmaking about environmental aspects related to the management of educational institutions constitutes a powerful tool for training, teacher professional development, and environmental literacies. A group of early childhood education teachers across various institutions work under a collaborative action-research model for an entire year that is focussed on the following: (1) the institution's water, solid waste, and energy management; (2) the planning of innovative activities related to water, solid waste, and energy, and; (3) participation in transformative actions that involve families and impact their neighbourhoods. The experience enables the building of a theoretical model of teacher training aimed at acquiring action skills from a comprehensive perspective of triple helix environmental literacy (management, research/innovation, and teaching) that affects their commitments to the management of environmental resources, the eco-auditing of their eco-school, the curricular greening of activities, the renewal of educational programs, and the implementation of an action-research focussed on aspects related to sustainability.
\end{abstract}

Keywords: education for sustainability; curricular innovation; sustainable management; teacher training; action research; water; waste material; energy; eco-school; early childhood

\section{Introduction}

This paper highlights the strengths of a model of curricular innovation and teacher training aimed at the training of teachers in various early childhood educational centres. Two teams of teachers (university academics and early childhood education teachers) work throughout an entire academic year from a collaborative action-research methodological framework. Throughout this study, we describe the phases of the model focussed on professional teacher training and its validation process. The acquisition of action competencies in the sustainable management and leadership of the centre, curricular greening, and action-research is evaluated. Early childhood education teachers from across a network of institutions audit the environmental dimensions of their centres, adopt sustainable measures, and consolidate an understanding of their strengths and weaknesses. The work is enriched by the participation of teachers from different centres in this training experience, particularly those interested in incorporating Education for Sustainability (EfS) as an activity of curricular innovation and for the environmental management of their schools.

The collaborative action-research experience developed with early childhood education teachers enables the construction of an educational management model that prioritises sustainability as a key element in the life of schools and acts as a stimulus for the teachers' professional growth and continuous training in specific educational activities, such as the solid waste management of the centre, the control of water consumption, energy 
expenditure and the use of alternative energies, mobility and travel activities through safe school roads coordinated with families, and other activities to mitigate climate change or the responsible production and consumption of products of proximity in school canteens and kitchens. The educational centre becomes an eco-school: an organisation conceived as an ecosystem that can be characterised as a mini-city made up of biotic and abiotic components, as sets of structures where interactions take place and decisions are made guided by principles of sustainability and environmental respect [1-3].

The main question we ask ourselves throughout the entire paper is whether early childhood education teachers can appropriate the three dimensions of sustainability (management, teaching, and research/innovation) assigned to the most prestigious professional categories of the higher levels of educational systems. It is widely recognised that university professors are those who develop research of high scientific impact, which is published in highly cited international journals, of high scientific prestige, providing universally contrasted and rigorous research findings: research that contributes to enriching the corpus of knowledge of a certain area of knowledge. In the last 30 years, public statements have been made in the different international convections where these three dimensions (management, teaching, and research/innovation) are defended as keys for the incorporation of sustainability in higher education. We highlight the convections pointed out by Wright (2004) [4] where this topic has been reflected on:

- Talloires Declaration (1990)

- Halifax Declaration (1991)

- Kyoton Declaration (1993)

- Swansea Declaration (1993)

- CRE Copernicus (1994)

- Declaration of Thessaloniki (1997)

- Lüneburg Declaration (2000).

These dimensions can also be seen described in different handbooks related to EfS in higher education, such as those of the authors Barth et al. (2018) [5] and Leal (2019) [6].

Traditionalist researchers tend to stand outside a situation and ask, "What are those people over there doing? How do we understand and explain what they are doing?" This kind of research is often called outsider or spectator research: the kind of theory they generate is usually abstract and conceptual and is communicated through words. However, action researchers are insider researchers. They see themselves as part of the context they are investigating and ask, individually and collectively, "Is my/our work going as we wish? How do we improve it where necessary?" If they feel their work is already reasonably satisfactory, they evaluate it and produce evidence to show why they believe this to be the case. If they feel something needs improving, they work on that aspect, keeping records and producing regular oral and written progress reports about what they are doing. The kind of theory they produce is dynamic and developmental and communicated through their actions as well as their words [7].

It is less frequent for teachers at other educational levels to undertake research tasks related to teaching. With this study, we propose to praise and vindicate the scientific value of the work carried out by early childhood education teachers in their modest preschool classrooms as a challenge to empower this educational level that is increasingly necessary for contemporary societies, but at the same time is undervalued and improperly acknowledged [8].

Assuming that a kindergarten teacher can provide relevant knowledge about their teaching practice is a daring and controversial hypothesis, especially given that the production of knowledge has been widely held sacred and regarded as a something prohibitive and inaccessible for the ordinary citizen [9]. Scientific movements in the field of psychology and educational sciences have been rigorously and tenaciously claiming the value of another type of professional knowledge and for types of practical theories that are less universal, more localised and functional, linked to the trends of research in the classroom [10], to the role of the teacher as a reflective professional [11,12], and to teaching as an 
evidence-based professional activity [13]. The logic that surrounds this type of knowledge is based on collaborative epistemological models that require the active participation of all agents of the educational community, and the framework on which it is based is that of participatory action research [14].

Early childhood education is not exactly the educational level that enjoys the highest reputation, prestige, privileges, and professional esteem in our societies [15]. Although no one disputes it has a necessary and essential function in the socialisation processes of children during their first years of life, the importance that this has for the personal development of children, and that the role of early childhood education is recognised as a decisive stage, but advocates criticise the scant financial investment, the sparse resources devoted to it, and the limited recognition given to this initial level of compulsory schooling. However, it is not surprising that during essential times, such as those we are living through at this stage in history, times subject to home confinements and population mobility restrictions as a result of a pandemic, educational administrations are insisting on the need to keep infantile and primary schools open [15-17].

This work aims to frame the training of early childhood education teachers through the following:

- $\quad\left(\# \mathrm{O}_{1}\right)$ Rethink a sustainable management model for early childhood education centres focussed on the management of water, solid waste, and energy.

- $\quad\left(\# \mathrm{O}_{2}\right)$ Reformulate the early childhood education curriculum from the EfS logic.

- $\quad\left(\mathrm{\#}_{3}\right)$ Provide sustainability action skills to early childhood education teachers.

\section{Theoretical Framework}

\subsection{Environmental Crisis}

The contemporary socio-environmental and health crisis, diagnosed as a systemic mismatch between the links that human beings establish with the biosphere, has entered a critical phase of worrying imbalance. The impact caused by COVID-19 is undermining options and opportunities for human development and social progress [18-21]. The close relationship that this health crisis has with the loss of biodiversity and the ecosystem balance shows the need to promote drastic measures for the conservation and defence of the environment as a safeguard to preventing future pandemics. At this point in history, we have not been able to find effective solutions to the great problems that beset the planet (climate change, extreme poverty and inequalities, wars and armed conflicts, the incessant violation of human rights, etc.) [8], and moreover, new threats are emerging that disrupt the well-being and progress that has been reached so far. The tragic presence of this virus places humanity before another disturbing truth-our fragile relationship with nature $[9,10]$. It is very time-critical to overcome the environmental, socio-educational, political, economic, and cultural consequences that this situation is causing globally. Educational institutions must equip themselves with innovative tools [22-25] to alleviate the effects of this pandemic and address other collateral issues that are becoming prevalent in the daily future of classroom life and in the activities and actions of teachers [26,27].

Civilisation is facing a traumatic clash with the biophysical limits of the environment. The inability of the biosphere to absorb, without altering its basic balances, the impacts of the socioeconomic metabolism derived from the ways of producing and consuming is all but confirmed. Likewise, there is obvious difficulty in ensuring sufficient resources for all its inhabitants to enjoy a dignified life within the framework of contemporary lifestyles [22]. Teacher training to make decisions and adopt actions committed to the management of environmental resources is an urgent challenge of our time. In this scenario, EfS emerges as an essential professional dimension of the 21st century in professions such as teaching $[17,28]$.

From the 2030 Agenda and the Sustainable Development Goals [29,30], the social and educational responsibility that educational institutions have at their initial levels as essential links, together with family actions [31-34], are called upon to generate and project spaces that favour the creation of a critical citizenry committed to addressing environmental 
problems $[31,32,35,36]$. Amongst the priorities that the 2030 Agenda proposes, Sustainable Development Goal (SDG) 4 pursues a "Quality Education", specifically in Goal 4.7, which notes that, "By 2030, we must ensure all learners acquire the knowledge and skills needed to promote sustainable development, including among others, through education for sustainable development and sustainable lifestyles, human rights, gender equality, the promotion of a culture of peace and non-violence, world citizenship and the appreciation of cultural diversity, and the contribution of culture to sustainable development" [30].

In these times of environmental and health crises, the ideas of educational movements that vindicate the advantages of learning outdoors, in close connection with nature, that connect schools with the environment through school gardens [37], green yards [38], and school outings [39], and open up new issues and challenges for the training of teachers in general and those of early childhood education in particular [40]. From this perspective, the early childhood education curriculum is presented as a set of controversial reasons and arguments that push and stimulate continued criticism, social and scientific development, innovation, progress, dignity, and human development, which are endless challenges and educators $[41,42]$ and, at the same time, a logical framework in which we can place EfS as a referent to address the professional development requirements of early childhood education teachers. This will contribute to equipping educators with theoretical-critical tools and action skills that allow them to address current socio-environmental needs in favour of a sustainable management model for education centres as well as favour an environmentalised curriculum development model [43] that is in line with the principles of sustainability, allowing them to plan meaningful and transformative educational activities for their students and at the same time ensure they are committed to a sustainable, supportive, and equitable ecological transition model [40,44-46].

\subsection{Sustainability as an Empowerment Tool for Early Years Teachers in Eco-Schools}

This research aims to show the potential that early childhood education teachers and their educational institutions can have as agents of transformation and socio-environmental change. Taking sustainability as the axis of their professional activities, the main challenge of this research lies in evaluating whether the three conventional dimensions of the scientific literature on sustainability that are widely addressed in Higher Education (environmental management, environmental research/ innovation and curricular greening) [47-50] are transferable to the context of early childhood education. Under this triple-dimensional prism, we identify the following dimensions in Figure 1, which serve as a conceptual framework for the work carried out by teachers at their schools:

- Curricular Greening. This refers to the incorporation of aspects related to sustainability in the content and pedagogical strategies that are made available to children, the use of environmental knowledge available to children, while at the same time developing a critical, systemic, and complex thinking of reality [51,52], internalising values related to environmental sustainability at an early age.

- Research and innovation in the classroom. Those institutions that include education for sustainability in their curriculum become centres that prepare citizens for the future and are part of the culture of complexity, fostering critical thinking in children, generating in them responsible behaviours towards the environment that surrounds them. These centres offer an education based on innovative activities that encourage participation and collaboration with the immediate environment from both a local and global perspective [53].

- Sustainable management of the eco-school. This refers to those behavioural guidelines that educational centres have in relation to the treatment of the resources available to them, aiming to encourage these behaviours to be committed to sustainable development in aspects such as water, solid waste, energy, mobility, green areas, as well as the responsible consumption and use of resources. Some authors defend the idea that coherent and ethical sustainable management strategies make the educational centre an organisation endowed with social responsibility [54]. 


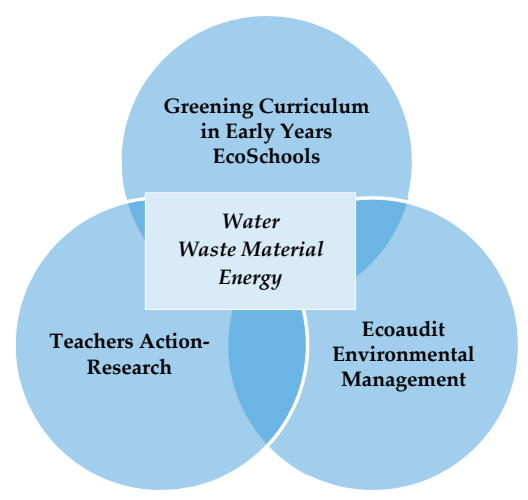

Figure 1. Triple dimensionality conceptual framework (prepared by the authors).

Based on this conceptual framework, four early childhood education centres are committed to sustainability; they assume the role of active agents in their community and serve as the engine for the educational paradigm shift that will contribute to the achievement of the SDGs proposed under the framework of the 2030 Agenda.

\subsection{EfS and Greening Early Childhood Education Schools}

Assuming that educational systems at different levels can transmit and reproduce a selection of content and cultural values gives rise to questioning a number of principles relating to models of curricular greening that they elicit about the environmental management models that prevail in early childhood educational centres or school organisations. Analysing the degree of environmental coherence that they promote and the alliances they establish with the educational community, with the neighbourhood and the territory in which they are located, with nearby green spaces, and with the institutions that surround them requires asking questions such as those related to the commuting to the educational centre, eating habits, water control, the use of solid waste, recycling, responsible consumption habits, the use of different types of energy, actions for the conservation of ecosystems and commitments to species in danger of extinction and the biodiversity of the territory, etc. At the end of the day, it is about integrating all these elements into a concept of development that is present in educational programs in an EfS format.

Framing early childhood education curriculum through the lens of the EfS has become a priority of study in recent years [55-59], which is also supported by United Nations Educational, Scientific and Cultural Organization (UNESCO) with its associated publications [60,61], and by OMEP (World Organisation for Early Childhood Education) itself with the design of the Environmental Rating Scale for Sustainable Development in Early Childhood (2015) [62] that marks a before and after rating in the evaluation/self-evaluation process of the early childhood education teachers on their teaching practice linked to the inclusion of sustainability. Nevertheless, there is still much to do, including the need to establish a coordinated logic between the management models developed by the centre, the teaching practice in the classroom, and the transfer of knowledge beyond the walls of the classroom and the institution. In this sense, the EfS is proposed as a tool that achieves the following:

- Helps the teacher train children who, through critical and collaborative thinking, can actively participate in society and with it, in decision-making.

- Generates and trains future citizens from the perspective of sustainability so that they are highly qualified to make responsible and consistent decisions.

- Promotes the development of theoretical knowledge, sustainability skills, pro-environmental values, which are transferable in the learner's daily life as practical learning.

- Favours active citizenship from the first years of life.

- Supports problem-solving skills and the search for shared solutions from a creative perspective. 
These theoretical approaches place EfS as a key tool for education in the new millennium, offering the possibility of addressing, from the prism of sustainability, important elements regarding the educational centre: sustainable management, curricular greening, equity in access to education, social inclusion, etc., which have become great challenges for teaching teams in the 21st century [63-65]. EfS is approached as a proposal articulated by four axes on which the gear of this transversal, holistic, and integral structure of doing education pivots $[52,66]$ (Figure 2).

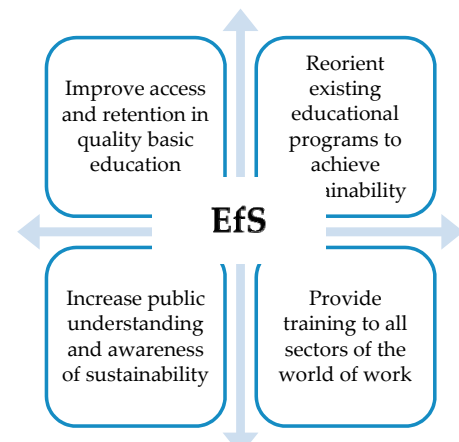

Figure 2. Axes on which the Education for Sustainability (EfS) pivots (prepared by the authors).

The challenge posed by the implementation of EfS is of such magnitude that it is essential to rethink the curriculum model in order to generate spaces, content, competences, and learnings based on the principles of sustainability, where children are considered to be part of the community where they live, in consonance and harmony with the rest of the earth's inhabitants and to take into consideration the synergies and interrelationships that exist $[67,68]$.

In short, EfS is emerging as a tool that has the power to alert educators and educational managers of new educational policies that take the inclusion of these approaches as a reference, which, in turn, bring with it an increase in sustainability practices that facilitate a change in the ways of doing, thinking, and being a 'citizen' [62]. In this task, dialogue, systemic thinking, collaborative work, anticipation, and other skills in sustainability become catalysts to facilitating educational tasks. "When children experience learning around wider dimensions of sustainability, there is the potential to develop genuine and critical understandings about global issues in a transformative and critical learning context" [69] (p. 1), which is a context that should serve as a reference for the sustainable management of early childhood education centres as well as for teacher training of this group of educators, as is discussed further on.

Tables 1-5 below show experiences related to the incorporation of EfS that are being carried out in different continents. This type of experience can serve as a reference for teachers committed to EfS to extrapolate actions in different contexts.

Table 1. Incorporating sustainability in the early years: experiences found in Africa. Prepared by the authors.

\begin{tabular}{cl}
\hline References & \multicolumn{1}{c}{ Observations } \\
\hline [70] & $\begin{array}{l}\text { This document shows the problems and challenges that teachers face in interpreting and implementing this } \\
\text { environmental education policy in four regions of Botswana. The data indicate that teachers applied various } \\
\text { normalisation strategies (self-government) in their contextual challenges, conceptions of environmental } \\
\text { education, support mechanisms, educators' experiences, and power relations. }\end{array}$ \\
& $\begin{array}{l}\text { This document defends the transformation of early childhood education for sustainable development, } \\
\text { teaching children environmental safety through play, personal hygiene, the proper use and disposal of waste, } \\
\text { and awareness of nature. They recommend the incorporation of sustainability in the curriculum and national } \\
\text { policy of early childhood education so that this is carried out in a satisfactory way. }\end{array}$ \\
\hline [71] &
\end{tabular}


Table 2. Incorporating sustainability in the early years: experiences found in America. Prepared by the authors.

\begin{tabular}{cl}
\hline References & \multicolumn{1}{c}{ Observations } \\
\hline [72] & $\begin{array}{l}\text { This book compiles different works related to the dissemination of sustainability and well-being values. In } \\
\text { Living Schools, the importance of transforming education from a perspective based on sustainability is } \\
\text { revealed through theoretical and practical proposals. }\end{array}$ \\
\hline [73] & $\begin{array}{l}\text { This document discusses the importance of training early childhood education teachers and managers as a tool } \\
\text { to include sustainability at an early age. }\end{array}$ \\
\hline
\end{tabular}

Table 3. Incorporating sustainability in the early years: experiences found in Asia. Prepared by the authors.

\begin{tabular}{ll}
\hline References & \multicolumn{1}{c}{ Observations } \\
\hline & $\begin{array}{l}\text { This study aims to analyse how the concepts of ECEfS (the meaning of sustainability, children as agents of } \\
\text { change for sustainability, and sustainability in the daily lives of young children) are represented in the national } \\
\text { curriculum documents of Australia and Korea through to critical document analysis. The study reveals that } \\
\text { individualistic and collectivist factors largely influence the configuration of the understanding of sustainability, } \\
\text { so it is important to incorporate the concept 'culture' as an essential dimension to the meaning of sustainability, } \\
\text { defining the identity of children with three ways of being (independent, interdependent, and relational), and } \\
\text { addressing the interactive and interconnected daily life of children. }\end{array}$ \\
& $\begin{array}{l}\text { This study evaluates government documents and secondary data over the past decade to determine the } \\
\text { accessibility, affordability, accountability, sustainability, and social justice of early childhood education (ECE) } \\
\text { services. The results indicated that ECE services have improved in the aforementioned dimensions, but that } \\
\text { some efforts still need to be made to increase the fiscal budget for ECE services and ensure the quality of } \\
\text { ECE services. }\end{array}$ \\
\hline 75$]$
\end{tabular}

Table 4. Incorporating sustainability in the early years: experiences found in Europe. Prepared by the authors.

References Observations

The study presents an example of using digital storytelling in a preschool class to raise awareness of sustainability issues. A linear digital storytelling was created, representing a local myth about watermills; then, [76] an educational intervention was conducted to raise awareness of local cultural heritage and sustainability issues. The results showed that digital storytelling was an effective educational tool for acquiring new knowledge and motivating the interest of preschool children.

This research focusses on young children's understanding of economic, social, and environmental sustainability. The participants were 43 children, aged 3-7 years, recruited from two kindergartens in Croatia. The findings indicate that kindergartens and preschools can provide the foundation for lifelong learning about sustainability, and important implications are that teachers can promote children's understanding through enriching pedagogical activities.

Table 5. Incorporating sustainability in the early years: experiences found in Oceania. Prepared by the authors.

\begin{tabular}{cl}
\hline References & \multicolumn{1}{c}{ Observations } \\
\hline [78] & $\begin{array}{l}\text { This article shows the effectiveness of arts-based pedagogies in exploring and understanding the natural } \\
\text { world in an early childhood program. The findings reflect the challenges educators must overcome to intensify } \\
\text { their connection to local settings and the effect that this connection has on their ability to reflect local natural } \\
\text { settings in their programs with children. }\end{array}$ \\
\hline & $\begin{array}{l}\text { This study, conducted in Queensland, shows how early childhood teachers do not have well-developed ideas } \\
\text { and practices in EfS, so they need a deeper understanding of sustainability to go beyond these teaching } \\
\text { practices. The authors suggest that it would be beneficial for early childhood teachers to have professional } \\
\text { development opportunities that build a deeper understanding of sustainability and its implementation in } \\
\text { their settings. }\end{array}$ \\
\hline
\end{tabular}




\subsection{Sustainable Management in Educational Centres through Internal Inter-Centre Eco-Audits}

From the perspective of positive psychology, recent research on EfS in the fields of attitudes, neuroscience and emotions has highlighted the essential role that participatory processes play in learning processes and behavioural changes [80]. It also makes explicit the ways in which participatory processes and bottom-up leadership in the management of educational centres contribute to promoting more effective and lasting changes in the educational agents involved [81]. The following list outlines the four factors in a sustainable and healthy eco-school that need to be considered by scientific literature in respect to the individuals, the groups, the organisations, and to the inter-organisational processes [82]:

- At an individual level, personal development and professional teacher training programs must consider motivation and active participation; promote well-being, resilience, passionate work, and the deployment of positive individual resources such as emotional intelligence, trust, and collaboration.

- At a group level, a healthy group is a group that respects its members, takes the time to listen to their points of view, plans actions together, tolerates different styles, and seeks solutions that are beneficial to all. Belonging to a team that works on shared tasks and common projects brings well-being to teachers, generates situations for development, offers training opportunities, creative thinking, common challenges, creates a culture of group identity, a predisposition to positive interaction with other teachers, facilitates the building of strong ties and social support strategies that are necessary to face complexities that can reduce conflicts in organisations.

- At an educational centre level, healthy organisations such as eco-schools must be open to facing challenges and to innovating in their leadership, management and organisation models. Their purpose is to make organisations more efficient and happier places, creating a culture of sustained creativity and innovation, promoting an organisational climate that supports positive relationships and leadership styles for the empowerment of teachers through autonomy and self-organisation.

- At an inter-organisational level, the focus is on making the boundaries of organisations more fluid and improving relationships between organisations. Partnerships, networking, and community participation are essential elements that bring mutual benefits.

All these socio-psychological factors play an important role in promoting environmentally responsible actions. Future teachers should have the necessary common values and organisational responsibility to take action for sustainability [83]. The experiences of collaborative action-research in eco-schools networks and the inter-centre work of staff and teachers favour the development of their own environments that are challenging and inspiring for the professional development of teachers, which are environments that in turn affect the four previous dimensions (individual, group, educational centre, and inter-organisation). The sustainable management of schools through internal eco-audit processes integrated into the governance of the institution involves these four dimensions of positive psychology mentioned above, promoting a multiplicative effect, contributing to a greater involvement of teachers in joint decision-making about the management of water, solid waste, energy, mobility, the maintenance and care of green areas, the acquisition of resources for the centre, responsible and sustainable consumption in school canteens, etc. All this is reflected in the planning of curricular activities linked to these environmental aspects that contribute to creating citizens committed to sustainability, with teachers playing a key role in all these processes. Figure 3 models this multiplier and empowerment effect brought about by work across inter-organisation networks that focus on innovative sustainable management models. 


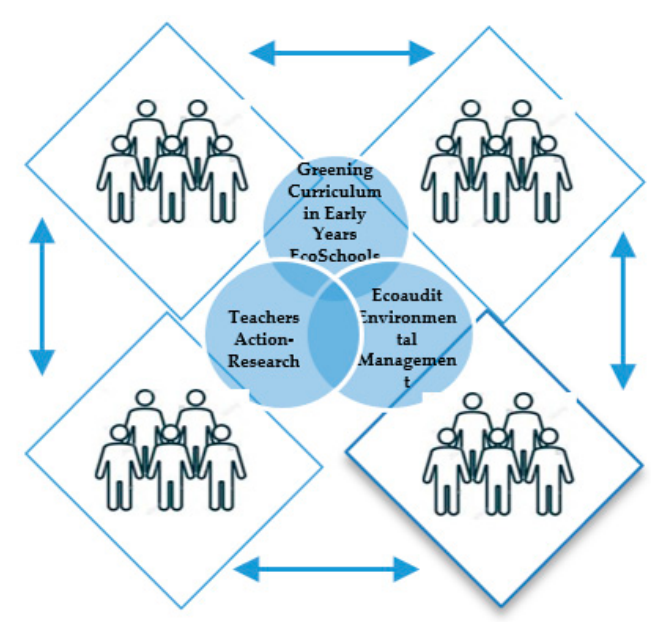

Figure 3. Multiplying effect of inter-centre networking (prepared by the authors).

A selection of experiences focussed on these three environmental dimensions shows evidence-based examples of how to incorporate these aspects into the sustainable management of eco-schools: water, solid waste, and energy.

\subsection{Educational Environmental Research on Water, Waste Material, and Energy}

\section{(a) Water Experiences}

Actions within this category should be oriented to highlight the importance of water as a key resource for life and raise awareness about the effects of its negligent use and consumption. EfS is a key strategy to increase public awareness and training related to sustainability and to empower everyone to make informed decisions regarding sustainability issues and environmental problems as water management in schools [83]. Actions should promote strategies to reuse and reduce water consumption, starting from the school and encouraging extrapolation and persistence of the acquired behaviours. Schools should analyse whether water consumption in their facilities is optimal or different actions could be implemented to improve it (notes in bathrooms, installation of waterless urinals, filling toilet tanks with sinks' sewer water, installation of drip irrigation systems, etc.). Feriver et al. (2016) [84] explore a range of transformations possible in the teachers' perspectives on environmental problems during and after the training workshops: influential factors in facilitating perspective transformation are shown to be the content, structure, and sequencing of the training, and peer support; and they conclude that transformative learning techniques offer a viable framework for engaging practicing early childhood teachers. Gutiérrez and Pirrami [85] explore a method on problem-based learning to commitment teachers in water issues and explore some obstacles to introduce active learning approaches to treat socio-environmental issues [85]. Other research uses new technologies as short videos on water [86] or video games to problematise sustainability water as a limited resource. For example, The Sun and Water project [87] is presented as an educational action through an electronic game which is based on regional problems on water that explored by means of information overload, virtual simulations, and real-world data; the game immerses preservice teachers in water management topics, biodiversity, sustainability, and human impact on the environment.

\section{(b) Waste Material Experiences}

Actions within this category including examining the impact of the waste generated by schools, exploring actions to minimise the amounts produced, and encouraging students to adopt similar strategies at home. The starting point of any action should be the inclusion of the waste concept in the curriculum. Students should understand different types of waste and their implications and effects in the environment. Borreguero et al. (2018) [88] show that current legislation gives no relevance to this concept, which translates, in turn, in the lack of its study in different educational stages. Before defining any waste-related 
action, schools must ensure that students understand the dimension of the problem and the objective of the actions that will be promoted. Arguably, the most popular actions related to this category are those revolving around the triple $\mathrm{R}$ (reduce, recycle, reuse). Among the three of them, recycling is typically part of most schools, in which different bins are provided to separate waste and different actions such as handicrafts with recycled materials take place. Research by Maddox et al. (2011) [89] expose a model that uses practical activities and the participation of schools to promote waste-related actions. This document describes and evaluates the effectivity of waste education to extrapolate actions to students' homes. A group of 39 schools was included in the project in which the objective was to transmit the triple $\mathrm{R}$ message to families. The study shows how the intergenerational influence can positively affect the recycling behaviour of the families based on a practical model based on waste education in schools. Then, this reflects the importance of the extrapolate of the actions carried out in schools as drivers of change in the attitudes towards waste management in the community.

\section{(c) Energy Experiences}

Actions within this topic should be based on looking for formulas in which all school members can work together to improve awareness of energy problems and improve the energetic efficiency of the school building. Eco-schools are focussed on energy as a main topic of the actions and changes in the centres. Energy policies in schools should not be a topic limited to the school board or managers. To achieve a profound effect both in the efficiency of the energy consumption of the schools and the awareness of the effects of energy wasting, it is necessary to involve families of students as active agents in the planned actions as a capacity of energy education to help solve climate change dilemmas and promote sustainability. Perkins (2014) [90] advocated for different experiences such as creating manual energy generators and the importance of management of energy for the conservation of the environment. A different action is found in López et al. (2016) [91], in which a solar energy cooking workshop was carried out in a eco-school: different devices prepared for cooking were used to show students the power of solar energy and how, by focussing solar beams, even an egg can be fried [91]. Game-based learning has been gradually adopted in energy education as an effective learning tool because digital games have the potential to increase energy literacy and encourage behaviour change [92,93].

\subsection{Early Years Research on Professional Development and Sustainable Action Competencies Acquisition}

Teacher training is necessary in order to generate educational spaces as well as curricula that is congruent with the principles of sustainability. This training will help to promote, for early childhood education teachers, key competences related to sustainability and teaching-learning models where infantile students participate and build their knowledge from practice in a creative way [65,94-96].

Early childhood education teacher training will facilitate their professional development and empower them to reflect on their own actions and the consequences of their teaching work to generate a sustainability competent citizenry [65]. In this sense, it is necessary to train teachers in certain key competencies that facilitate the professional development of early childhood teachers from the prism of an innovative methodology that combines knowledge and practice; that focusses on criteria related to ethics, social justice, solidarity, and respect for the environment in the generation of such knowledge; that incorporates educational models focussed on project-based learning, and rethinks school management models, moving toward those based on the principles of sustainability [97].

Therefore, in this training for early childhood education teachers, a training that is multidimensional and that implies knowing, understanding, acting, and being must be advocated for [68] — training endorsed by the development of key competencies related to sustainability, which highlight the integral perspective that education for sustainability implies $[65,68,96,98]$ (Figure 4). 


\begin{tabular}{|c|c|c|c|c|c|c|c|c|c|c|c|}
\hline $\begin{array}{l}\text { Recognize } \\
\text { and } \\
\text { understand } \\
\text { relationships } \\
\text {, identifying } \\
\text { and connecting } \\
\text { ve the } \\
\text { economic } \\
\text { and social } \\
\text { dimensions } \\
\text { of a problem }\end{array}$ & $\begin{array}{l}\text { Understand } \\
\text { and } \\
\text { evaluate } \\
\text { multiple } \\
\text { alternative } \\
\text { paths and } \\
\text { changes for } \\
\text { the future }\end{array}$ & $\frac{\text { con }}{\frac{\pi}{4}}$ & $\begin{array}{l}\text { Understand } \\
\text { and reflect } \\
\text { on the } \\
\text { norms and } \\
\text { values that } \\
\text { underlie our } \\
\text { actions } \\
\text { towards } \\
\text { sustainabilit } \\
\text { y }\end{array}$ & 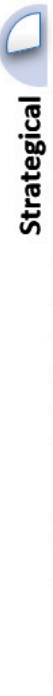 & $\begin{array}{l}\text { Contextualiz } \\
\text { e actions } \\
\text { that } \\
\text { promote } \\
\text { sustainabilit } \\
\text { y, } \\
\text { identifying } \\
\text { the different } \\
\text { dimensions } \\
\text { of a problem } \\
\text { or action, } \\
\text { spatial } \\
\text { dimension } \\
\text { (local- } \\
\text { global) and } \\
\text { temporal } \\
\text { dimension } \\
\text { (past, } \\
\text { present and } \\
\text { future) }\end{array}$ & $\begin{array}{l}0 \\
0 \\
\frac{0}{0} \\
\frac{0}{0} \\
\frac{0}{0}\end{array}$ & $\begin{array}{l}\text { Learn from } \\
\text { others, } \\
\text { understand } \\
\text { and respect } \\
\text { the needs } \\
\text { and opinions } \\
\text { of others, } \\
\text { solve } \\
\text { problems in } \\
\text { a } \\
\text { collaborativ } \\
\text { e and } \\
\text { participatory } \\
\text { way }\end{array}$ & ( & $\begin{array}{l}\text { Questioning } \\
\text { norms, } \\
\text { practices } \\
\text { and } \\
\text { opinions, } \\
\text { and } \\
\text { reflecting on } \\
\text { values, } \\
\text { perceptions } \\
\text { and own } \\
\text { actions }\end{array}$ & 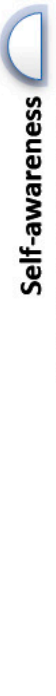 & $\begin{array}{l}\text { Self- } \\
\text { reflection on } \\
\text { one's local } \\
\text { and global } \\
\text { role, } \\
\text { evaluate } \\
\text { one's } \\
\text { actions, and } \\
\text { manage } \\
\text { emotions } \\
\text { and feelings. }\end{array}$ \\
\hline
\end{tabular}

Figure 4. Action competences on sustainability [68].

This competence framework shows that the professional development of early childhood education teachers moves through a continuous training cycle that stimulates a process of critical reflection in order to make these educators question their beliefs $[99,100]$ and to generate a process of self-regulation and self-evaluation in regard to their objectives as well as the control of the teaching-learning process, appealing to the development of these competences in the students also. The need to generate models of teacher leadership and the empowerment of the entire educational community is evident in order to generate management structures for educational centres based on the principles of sustainability, which is a challenge that is addressed in this research.

Research on EfS has a long tradition of working with Collaborative Action Research (CAR) methodologies due to the transforming peculiarity and the intrinsic demands for change promoted by environmental education programs linked to formal education [101-104] or in non-school intervention contexts of community intervention and improvement of the sustainability conditions of the territory [101-106].

A large number of CAR-inspired experiences of innovation and curriculum change have helped to significantly improve EfS methodologies and programs from the middle of the last century. In some cases, these are linked to Eco-School Networks $[107,108]$ under the guidelines and methodologies of the European Foundation for Environmental Education, while in others, they assume the label of School Agendas $21[109,110]$ in coordination with municipal networks for collaborative endeavours. The ENSI Project (Environment and School Initiatives Project) deserves a special mention as a collaborative European network with a long tradition of innovative contributions that have transformed a large number of school programs and trained a large number of teachers from the following premises [111,112]:

1. That participating teachers adopt a research perspective in respect to their own teaching and curriculum activities: the participating teachers were asked to systematically reflect on their own activities in order to improve them and in order to contribute to their own and other people' knowledge of environmental education. In other words, they should involve themselves in action research.

2. That selected schools demonstrate (if at varying degrees of intensity) environmental education curriculum activities characterised by the adoption of a research perspective: personal involvement of students and emotional commitment, interdisciplinary learning and research, reflective action to improve environmental conditions, and involvement of students, at least partially, in decision-making on problem-finding, on procedures, and on monitoring their work.

3. Rather than confining teachers to the role of technical implementers of the curricula designed by others, the project encourages teachers to participate in research of their 
own that is conducted by and is of concern to them, creating a model of environmental education that is community based and action orientated and for a higher professional role for teachers as researchers.

\section{Eco-School Context and Research Agents}

The following agents have participated in this research:

(a) A group of academics from the University of Granada who are experts in environmental education research (external agents);

(b) The staff of the Granada Educa Foundation, a public network of early childhood education centres in the city of Granada, Spain;

(c) A group of early childhood education teachers from the network of centres that belong to the foundation (internal agents).

The four centres that are the object of this study have a total number of approximately 118 students per centre divided into six age groups that range from 0 to 6 years old. The teaching teams at each institution are made up of 10 teachers, and there are 2 cooks at each centre that have been classified as service personnel.

These are institutions with a high degree of awareness in regard to respect for the diversity and social and personal realities of their environments, and they know how to make good use of this awareness in a number of projects addressing the institutioncommunity relationship [113].

The four schools are equipped with an educational environment designed and adapted to the needs and characteristics of children where they are respected for their individuality and considered to be active interlocutors in their relationship with the world, with their peers, and with adults. The gradual development of their autonomy is also favoured and by trusting in their growth potential, relationships and encounters with others are promoted, favouring the child's socialisation. Children are the protagonists of their own learning, and in addition, the families understand and participate in the educational project, and teachers form an educational team with great experience and an innovative spirit $[113,114]$.

The relationship with the immediate environment is an important part of the day-to-day life of early childhood centres. These are related to the physical and sociocultural environments in which they are located, in each neighbourhood to which they belong. All events, interactions, and incidents constitute a very valuable resource in the daily life of the centres.

It is part of their work approach to take advantage of the resources and possibilities of knowledge that the environment offers them, to encourage the participation of children in it to enrich their experiences, and to establish relationships in the various spaces that are part of the neighbourhood: health care centre, library, shops, parks, museums, etc. [113].

An important part of their educational project is related to environmental education. A number of these four centres have facilities dedicated exclusively to environmental education, such as orchards, greenhouses, large green areas, etc.

Centre 1 (Figures 5 and 6) is located in the emblematic Albayzin neighbourhood. It is a privileged environment and is one of the city's historic neighbourhoods.

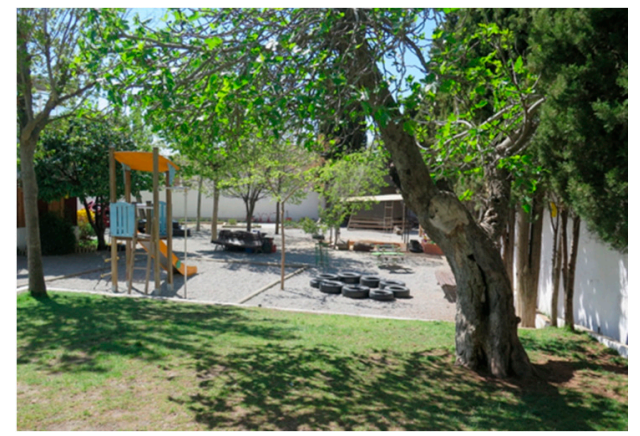

Figure 5. School \#1: Sample of external and internal facilities. Images retrieved from https:/ /www. fundaciongranadaeduca.org/ [115]. 


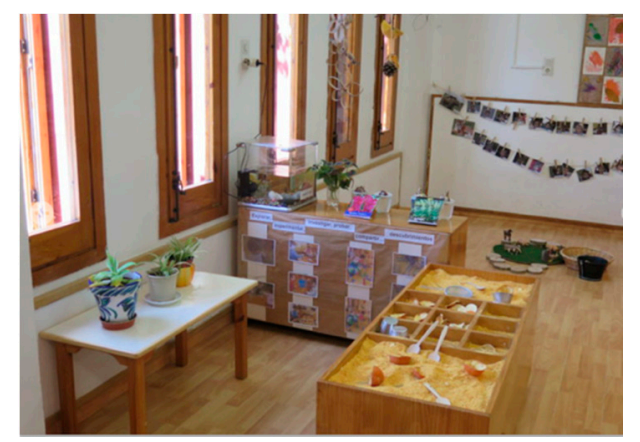

Figure 6. School \#1: Sample of external and internal facilities. Images retrieved from https:/ /www. fundaciongranadaeduca.org/ [115].

Centre 2 (Figures 7 and 8 ) is located in a strategic spot that provides the institution with access to various neighbourhoods in the southern part of the city.

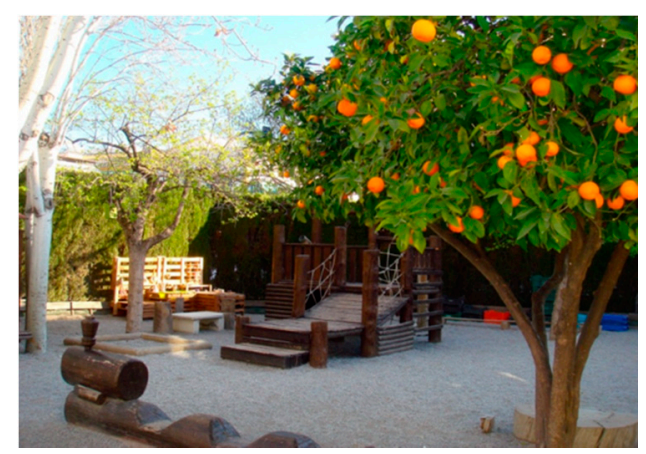

Figure 7. School \#2: Sample of external and internal facilities. Images retrieved from https://www. fundaciongranadaeduca.org/ [115].

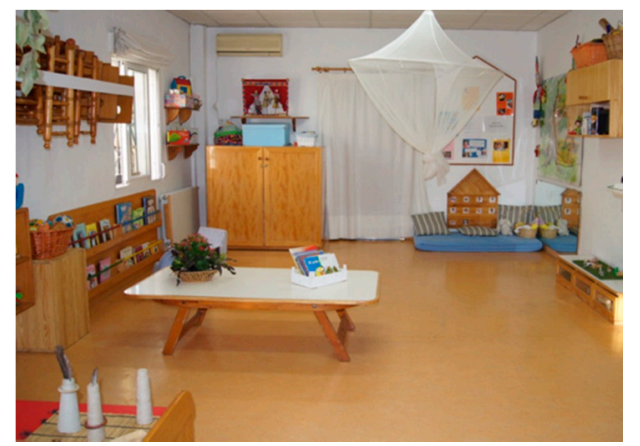

Figure 8. School \#2: Sample of external and internal facilities. Images retrieved from https:/ / www. fundaciongranadaeduca.org/ [115].

Located at the junction between the Central District and the Genil River, Centre 3 (Figures 9 and 10) has a two-story space and several gardens.

Finally, Centre 4 (Figures 11 and 12) is located in one of the peripheral neighbourhoods in the north area of Granada. The building was originally designed as a nursery school, so it has one floor and large gardens. 


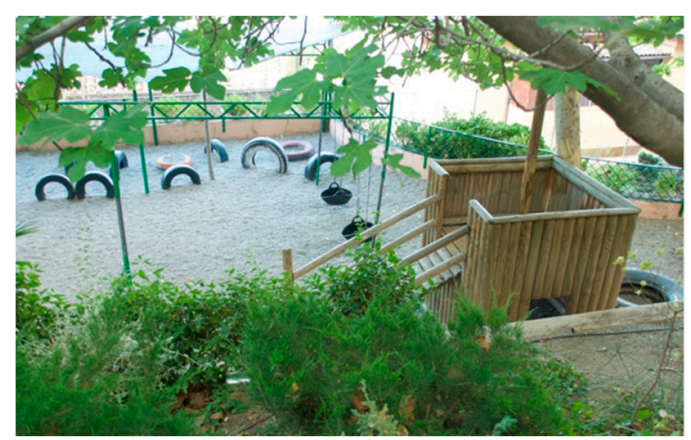

Figure 9. School \#3: Sample of external and internal facilities. Images retrieved from https://www. fundaciongranadaeduca.org/ [115].

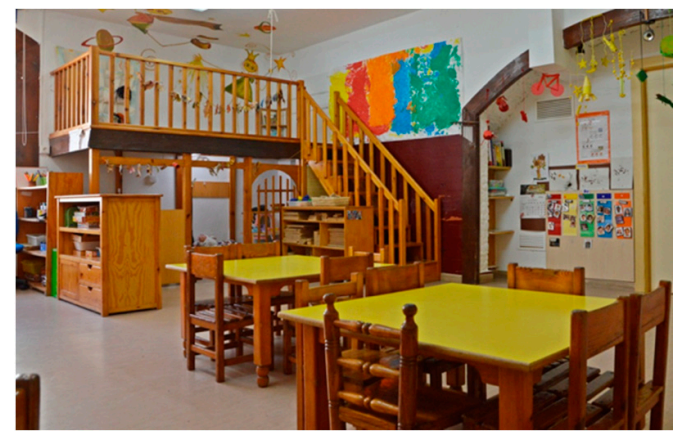

Figure 10. School \#3: Sample of external and internal facilities. Images retrieved from https:/ /www. fundaciongranadaeduca.org/ [115].

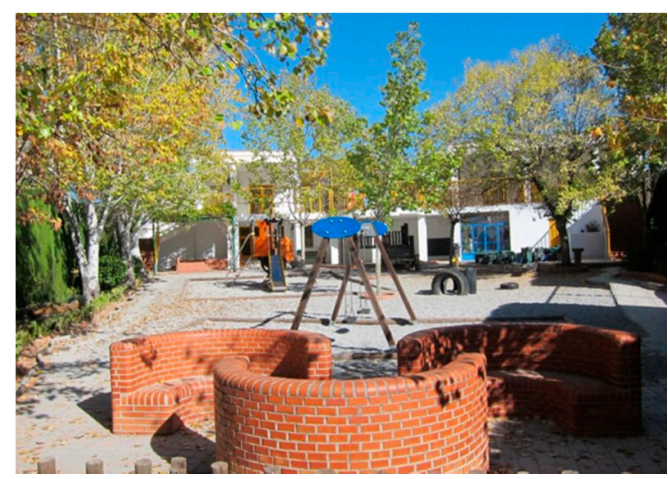

Figure 11. School \#4: Sample of external and internal facilities. Images retrieved from https:/ /www. fundaciongranadaeduca.org/ [115].

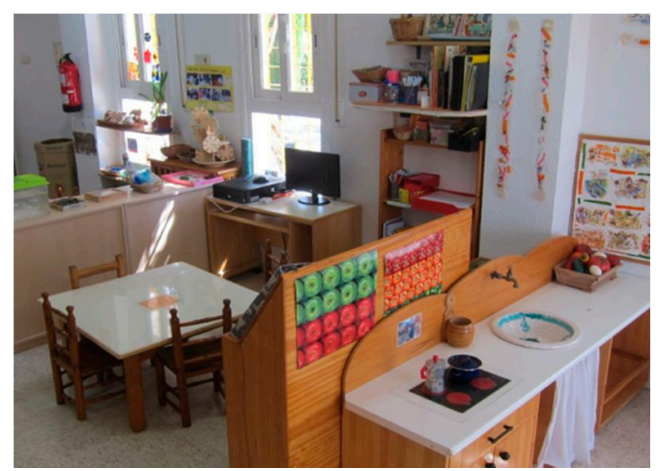

Figure 12. School \#4: Sample of external and internal facilities. Images retrieved from https:/ /www. fundaciongranadaeduca.org/ [115]. 


\section{Materials and Methods}

\subsection{Collaborative Action Research as a Method for Curricular Greening in Early Childhood (Infantil) Education}

Collaborative Action Research (CAR) has become increasingly popular around the world as a way for all people to take action in professional practices, as a form of professional learning across the professions and disciplines, in their personal and social situations with a view to improving them. It is particularly well developed in education, specifically in teaching and in professional EfS $[116,117]$. More groups of practitioners are getting together to investigate their collective work and put their stories of learning into the public domain $[118,119]$. CAR is conceptualised as a practical form of enquiry that enables anyone in every job and walk of life to investigate and evaluate their work. They ask, "What am I doing? Do I need to improve anything? If so, what? How do I improve it? Why should I improve it?" They produce their accounts of practice to show the following: (1) how they are trying to improve what they are doing; this involves first thinking about and learning how to do it better; (2) how this enables them to give meaning to their lives; and (3) how they are trying to influence others to do the same thing. These accounts stand as their own practical theories of practice, from which others can learn if they wish. Teachers as practitioners research their own practices, which is different from most traditionalist forms of research where a professional researcher does research on rather than with practitioners [120].

EfS CAR help develop improvements at various levels (individual, leadership capacity throughout organisations and across interschools). This same commitment is reflected throughout the development of its programmes and its focus on specific teaching and learning strategies, including the central importance of personal experience in learning; the importance of the learning climate; the involvement of learners in the identification of learning needs; the involvement of learners in the development of the learning experience, with tutors acting as guides and content resources; and the mutual responsibility of learners, family, and teachers for managing and developing positive learning experiences.

EfS CAR is widely seen as a methodology for real-world social change. People communicate their ideas as theories of real-world practice by explaining what they are doing, why they are doing it, and what they hope to achieve together. These personal theories are dynamic, in-the-world theories; they change and develop as people themselves change and develop collective actions and commitment. The aim of practitioners using a collaborative action research approach is to generate their personal and collective theories about how their learning has improved practices and is informing new practices for themselves and others [120]. Our research proposes a model of teacher training focussed on their professional development and aimed at acquiring action skills from a comprehensive perspective of environmental literacy. The objective we pursue with the creation of this model is to empower early childhood education teachers by providing them with instruments that promote their professional development. This is made possible by having an understanding of the work they do every day and leading an in-depth analysis of their realities through a collaborative process with their group of peers guided by the university's research group expert in the field.

Participating in this process leads to an early childhood educator's embarking on a path oriented towards the construction of theories that serve as the foundation of their own professional practice, thus training them, through the tools available to them, to employ a type of science that is based on decision-making in favour of the incorporation of sustainability within their immediate environment.

This model has four phases that are interconnected by two transversal actions linked to the monitoring process and the process of participation, leadership, and empowerment of the entire educational community for the greening of the educational centres under study (Figure 13). 


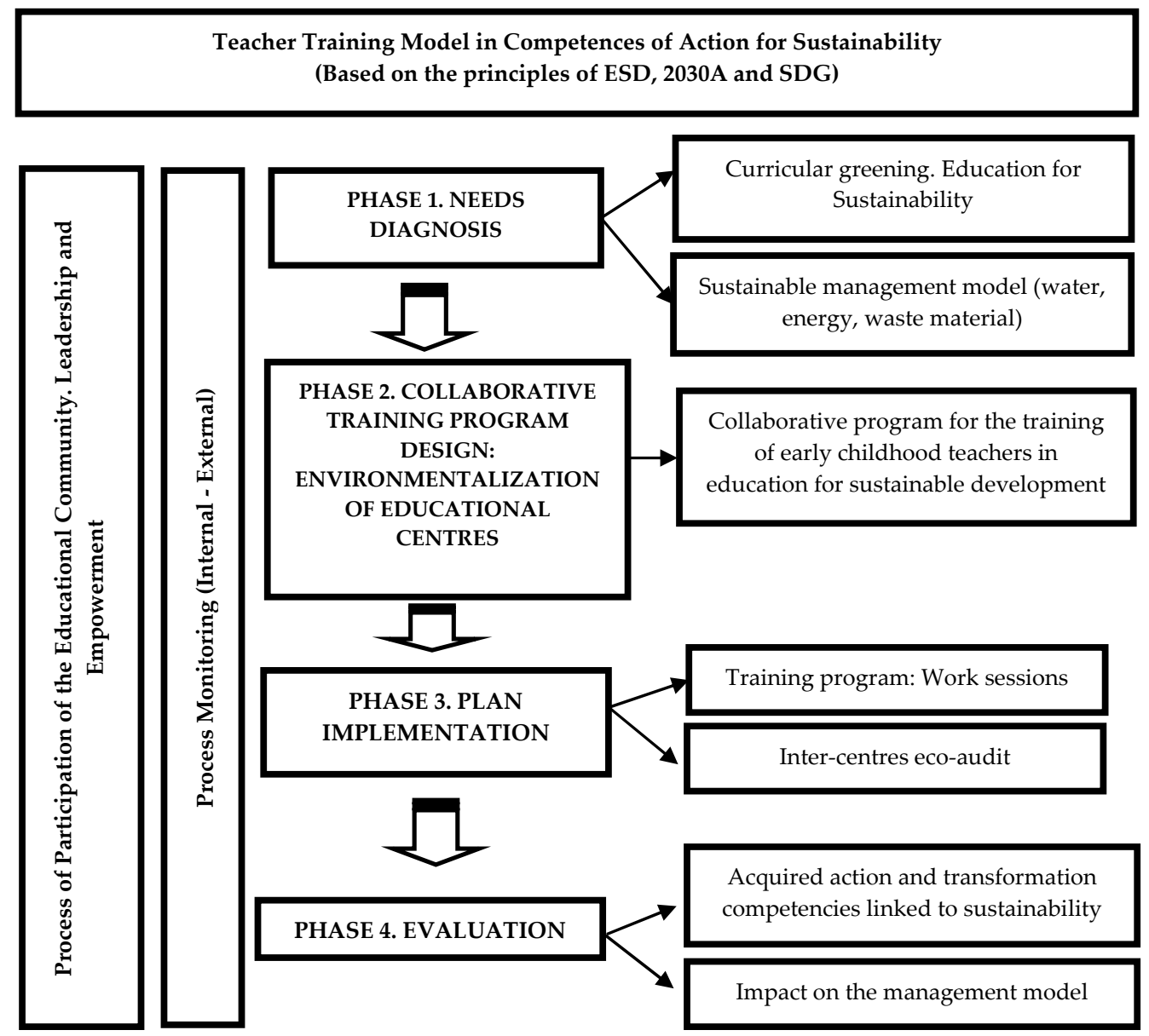

Figure 13. Environmental literacy process in educational centres (prepared by the authors).

Based on this collaborative action-research model implemented at the centres studied, outlined below is each of the central phases of the model and the strategies that have made it possible to collect information to validate it as a model of environmental literacy in early childhood education centres.

\subsection{Phases and Instruments for Collecting Information}

\subsubsection{Phase 1: Needs Diagnosis}

Phase 1 of teacher training proposed in this study focusses on a needs assessment using two information gathering instruments:

(1) An ex_ante evaluation questionnaire on curricular greening with nine items on the experience and professional practice of teachers in relation to sustainability and with three answer options that varied according to the questions asked (None, some, and quite) or (No, I don't know, and yes).

(2) A change evaluation scale with 15 statements related to the incorporation of sustainability in the curriculum, so teachers can indicate their degree of agreement using a 5 -point scale from 1 (strongly disagree) to 5 (strongly agree).

The information collected through these instruments has allowed us to characterise the experience that early childhood education teachers have and their perceptions of EfS and the sustainable management of their centres.

\subsubsection{Phase 2: Designing of a Collaborative Training Program}

Phase 2 of the training model focusses on the design of training activities that respond to the needs identified in Phase 1. Early childhood education teachers, university experts in EfS, and staff from the Granada Educa Foundation were brought together as a working 
group to design a collaborative training action that would be included in the foundation's strategic training plan. This training action allows us to reflect on the meaning of EfS, to carry out practical creation workshops with recycled materials, moving closer to the natural environment and discovering the educational possibilities it offers, as well as closely examining experiences and innovative proposals to work both at an institutional and classroom level. All actions were aimed at early childhood education teachers acquiring the necessary action skills to include sustainability in the early childhood stage curriculum.

\subsubsection{Phase 3: Implementation of the CAR Program}

Phase 3 is dedicated to the implementation and development of the collaborative training action through the different sessions proposed in the design phase explained above.

During the implementation phase, the program's process evaluation was carried out through an eco-audit, which is presented as an instrument that allows the evaluation from practice and environmental improvement of educational centres. This tool enabled the centres themselves to reflect on their environmental management, articulate possible errors, and enforce any necessary improvements to increase the environmental quality of the educational centre and its most immediate surroundings.

For this occasion, the decision was made to carry out an Inter-Centre Eco-Audit, as the majority of attendees were from different centres and performed the role of evaluators (auditors) from a school other than their usual workplace.

As part of the Inter-Centre Eco-Audit process, a template was developed with a SWOT structure (Strengths, Weaknesses, Opportunities, Threats), so that the subjects, organised into three groups, could identify strengths and weaknesses with respect to the dimensions of sustainable management within the educational centre (energy, solid waste, and water). Each group was tasked with one category and would feed this information back to the wider group, generating, through a process of participation and collaborative work, a series of conclusions focussed on proposals for improvements regarding the environmental management of the centre under audit.

\subsubsection{Phase 4: Evaluation of Impact and Results}

In the final phase of the study, emphasis was placed on evaluating the results of the training proposal, so we analysed the impact that the collaborative training action generated in the teaching practice of the participating teachers, evaluating the degree of acquisition of action and transformation competences of its practice and sustainability commitments.

In this case, to measure the impact of the training action, the decision was made to expand the sample and collect information on the changes and improvements produced in teaching practices after the start of the program-not only from the teachers that participated in the collaborative training action but also those of teachers from the educational institutions involved who did not participate directly. This was carried out to observe the impact and multiplier effect generated by the activities regarding the implementation of actions related to EfS at the participating centres.

For this, two instruments were designed: an interview and a value scale.

(1) The purpose of the interview was to qualitatively analyse those teaching practices related to SE that were incorporated into early childhood schools after the start of the training action. To this end, a protocol was developed consisting of 42 open questions organised into two categories (curricular innovation and sustainable management model of the centre).

(2) The value scale on the greening of early childhood education centres and their commitment to sustainability focussed on quantitatively analysing those categories raised during the interviews that were most valued by early childhood education teachers after applying the training action. The scale consisted of 15 items with five response alternatives where 1 corresponded to not at all satisfied and 5 corresponded to very satisfied. The aim of this scale was to enable teachers to respond after reflecting 
on their satisfaction level with respect to the work carried out across each of the dimensions addressed.

\subsection{Sample}

The sample participating across the different phases involved 30 early childhood education teachers $(86.7 \%$ female and $13.3 \%$ male) with different levels of involvement in a total of 114 participation actions throughout the process: (1) the diagnostic questionnaire (Phase 1 ) had 15 subjects (93.3\% female and 6.7\% male); (2) the assessment scale (Phase 1) had nine participants where $100 \%$ were female; (3) the training collaborative action was broken down into work sessions (Phase 2) with 15 participants (93.3\% female and 6.7\% male); (4) 15 subjects (93.3\% female and 6.7\% male) collaborated in the Inter-Centre EcoAudits (Phase 3), and finally; (5) in Phase 4, the interview and value scale, there was participation of 30 subjects ( $86.7 \%$ female and $13.3 \%$ male) in each of the instruments.

\subsection{Quantitative and Qualitative Data Analysis}

The data analysis process has been carried out through the use of a mixed research method that involves the use of qualitative and quantitative techniques. The analyses carried out seek to visualise the changes that the CAR model has generated both in the educational centres and in the teachers in regard to the transformation and professional development that teachers experienced after completing the training process. The analysis carried out has been supported by the use of different software that has facilitated the analytical task.

\subsubsection{Qualitative Data Analysis}

MAXQDA version 2020 was chosen for the analysis of qualitative information as it allowed us to analyse the content through the categorisation of the testimonies collected in the interviews as well as to perform the coding required to create different resources such as code matrices, segments, word clouds, etc., following the process set by authors such as Miles, Huberman, and Saldaña (2014) [121] (Figure 14).

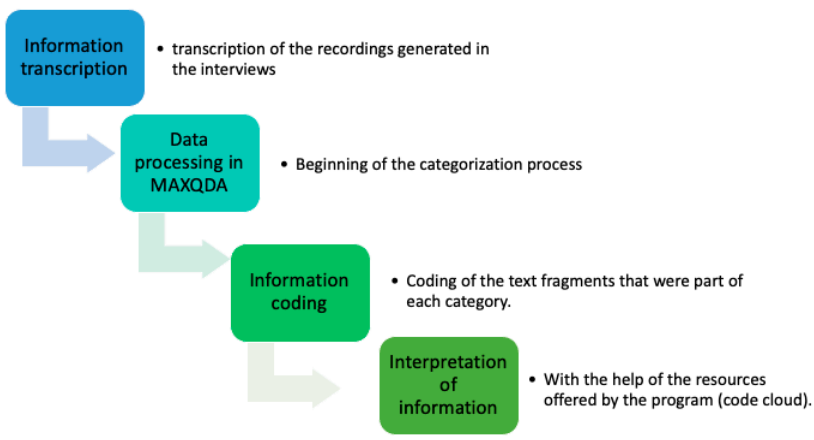

Figure 14. Stages of qualitative data analysis procedure. Prepared by the authors.

Following Bernard and Ryan (2010) [122]; Spencer, Ritchie, Ormston, O'Connor and Barnard (2014) [123]; and Wood and Smith (2018) [124], some of the strategies with which we have ensured the validity of the process followed include the detailed explanation of the process followed in the analysis of the information, the reading and coding of the contributions by more than one researcher, and the triangulation of the interpretations made.

Likewise, the quality criteria indicated by Miles and Huberman (1994) [125] have been considered: credibility, confirmability, transfer, and dependence. In order to ensure valid development of the research that we have carried out, those criteria that we consider to be most relevant have been selected without casting aside those criteria that could represent negative evidence for our work. Therefore, we have carried out a methodologically adequate collection of information without constricting the results obtained in the data analysis carried out. 
The categories of analysis that have emerged in this qualitative research process are structured in two large dimensions: an environmental management model of the centre on aspects of water, waste, and energy; and potential for teaching research and curricular innovation on collaborative work, social climate, and curricular transversality in EfS. Figures 15 and 16 detail the units of analysis of these large categories, organised in their corresponding dimensions and sub-dimensions.

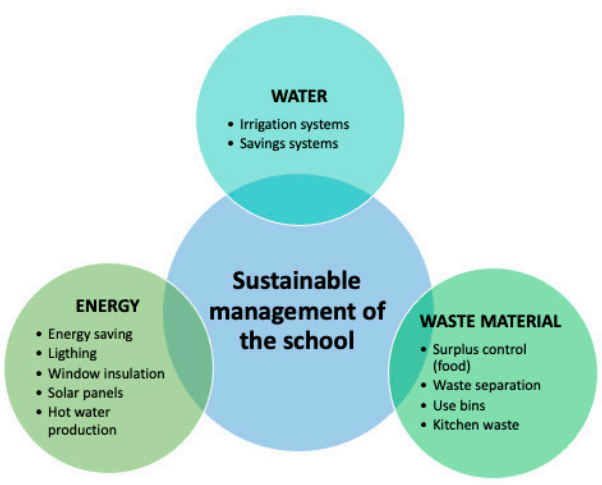

Figure 15. Units of analysis in the category sustainable management of the centre. Prepared by the authors.

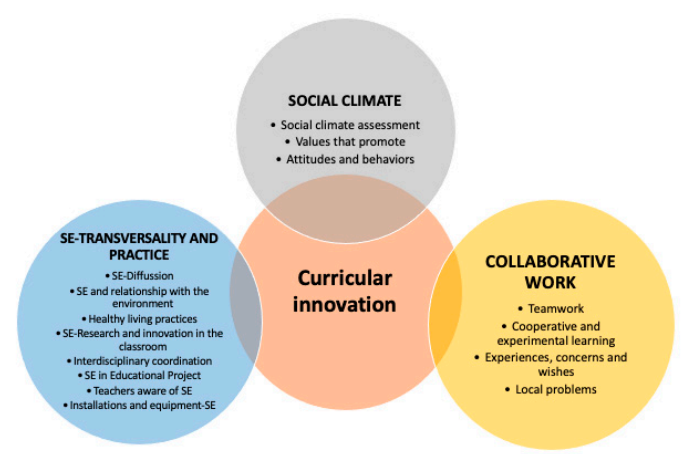

Figure 16. Units of analysis in the category curricular innovation. Prepared by the authors.

\subsubsection{Quantitative Data Analysis}

In the case of quantitative data, we have used the Statistical Package for Social Science (SPSS version 26), which has allowed us to carry out the pertinent descriptive analyses. Table 6 shows the analyses performed for each instrument.

Table 6. Quantitative data analysis techniques. Prepared by the authors.

\begin{tabular}{|c|c|c|c|}
\hline Instrument & Variable & Analysis & Statistics \\
\hline $\begin{array}{l}\text { Diagnostic questionnaire (Phase 1) } \\
\text { Assessment Scale (Phase 1) } \\
\text { Assessment Scale (Phase 4) }\end{array}$ & $\begin{array}{l}\text { Independent } \\
\text { Dependents }\end{array}$ & Descriptive & $\begin{array}{l}\text { Measures of central tendency } \\
\text { Measures of dispersion } \\
\text { Frequencies and percentages }\end{array}$ \\
\hline
\end{tabular}

Quality criteria for these instruments:

- Regarding the validity of the diagnostic questionnaire, we have considered the content validity and the criterial validity, since it is not possible to calculate the construct validity due to the small size of the sample to which it has been administered. Content validity has been ensured through expert judgment. Regarding the concurrent criterial validity, we highlight that the corrected item-total test correlations applied to items Q1 to Q5 has been higher in two of the four items analysed, since item 5 has been suppressed as its variance has a value $=0$. On the other hand, the highest percentage of explained variance (quadratic multiple correlation coefficient) corresponds 
to item 4 with $34.5 \%$ and the lowest percentage corresponds to item 3 , with $5.8 \%$ of explained variance.

- Regarding the reliability as internal consistency achieved by the questionnaire, taking into consideration the five items with a response in Likert format, we must highlight that a coefficient value of Cronbach's alpha $=0.50$ has been achieved. This value can be considered insufficient to affirm that it is a consistent scale, but taking into account the number of participants that make up the sample $(n=15)$, the small number of items, as well as the number of responses (only three), is more than enough. It is for this reason that we believe it is necessary to analyse the questions and answers in greater detail as well as the suitability of said indicator to determine the validity of the instrument in question.

- In the evaluation scale of Phase 1, we highlight the concurrent criterial validity because the corrected item-total correlations applied to items A1 to A15 with five response levels on a Likert-type scale achieved a Pearson's coefficients item-total test excluding the item in question (corrected) above $r=0.30$ and with a positive sign in a large number of the items analysed. In this case, the reliability of the instrument is moderately low (Cronbach's alpha 0.52), which is justified by the low number of participants to which the instrument has been administered.

- The quality of the evaluation scale used in Phase 4 was assured in regard to the content validity through the judgment of experts and from the criterial validity; in relation to the latter, we must emphasise that, as was the case in the previous questionnaire, the items have achieved item-total corrected test correlations close to or greater than $r=0.30$ and with explained variance percentages of $93.1 \%$ (the highest) in the case of responsible consumption and $64.7 \%$ (the lowest) in collaborative work, which was inferred from the calculated multiple quadratic correlation coefficients.

- In the case of reliability, Cronbach's alpha has been calculated individually for each of the three categories with a total value of 0.63 .

\subsubsection{Triangulation of Quantitative and Qualitative Information}

In the research that we reflect in this article, the framework involved in the implementation of each of these phases is brought to light from the perspective of complexity, and so it has been indispensable to carry out a triangulation process based on the plurality in the use of information-gathering techniques and key informants that has resulted in strengths, weaknesses, and proposals for improvement. Figure 17 details this process of the triangulation of the information carried out where the interrelation of results stands out, taking into account the different information collection instruments use, as well as the sources consulted. This triangulation has allowed us to collect enough information for the validation and modelling of our collaborative training proposal on sustainability for teachers from a collaborative action-research approach.

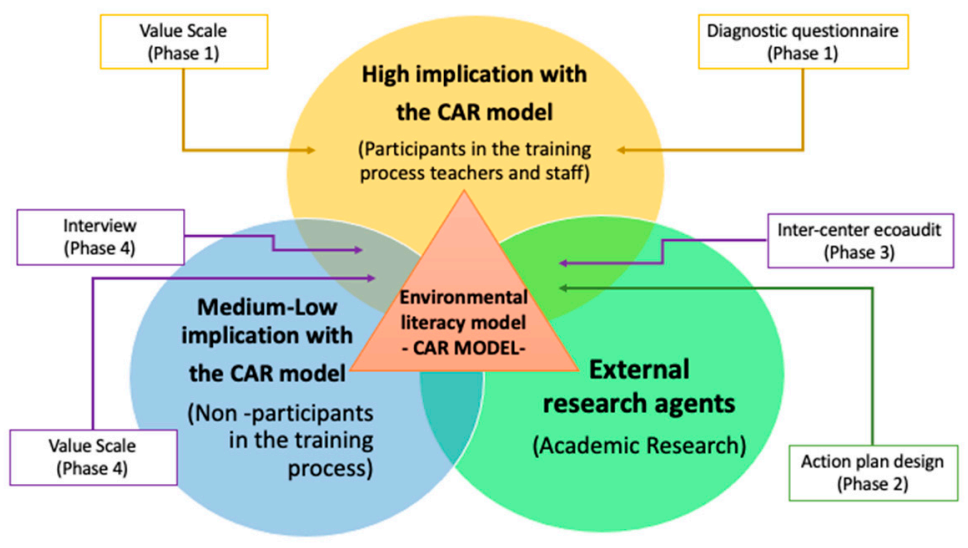

Figure 17. Process of triangulation of agents and instruments: Creation of the environmental literacy model. Prepared by the authors. 
This will allow us to set basic guidelines of good practices carried out by early childhood education teachers who have governed this model of environmental literacy in educational centres linked to compliance with the 2030A and SDGs from the prism of Education for Sustainability.

\section{Results}

\subsection{Results Derived from Phase 1: Needs Diagnosis}

The collected data have allowed us to carry out a diagnosis based on the weaknesses and strengths that early childhood teachers have regarding incorporating sustainability into their daily practice. The questionnaire and the change evaluation scale have allowed us to identify which items are the best valued by teachers (strengths) as well as those items that are not paid as much attention or that are most neglected, identifying them as deficiencies that should be worked on and attempted to mitigate.

Regarding the ex_ante evaluation questionnaire, it should be noted that there is unanimity among the participants in considering the participation of early childhood education teachers in training actions related to sustainability as necessary and essential $\left(\mathrm{M}_{\mathrm{e}}=3.00\right)$ because, as they state in their answers, they recognise their low training in the field of EfS $\left(\mathrm{M}_{\mathrm{e}}=1.75\right)$ as well as their little familiarity with this term and all that it entails $\left(\mathrm{M}_{\mathrm{e}}=1.50\right)$ (Figure 18).

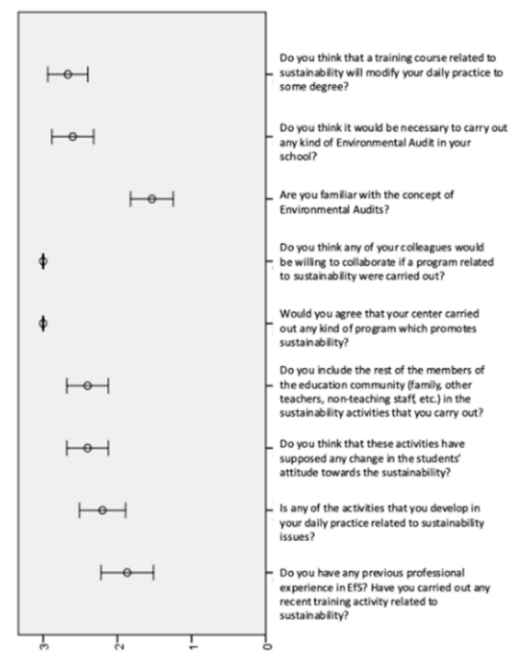

Figure 18. Average of responses (ex_ante evaluation questionnaire).

In the change evaluation scale and taking into account the multivariate content classification using hierarchical cluster analysis through "mean bonding (between groups)", three clusters can be established that identify the grouping of the items based on the responses (Figure 19).

\#Cluster 1: items 12, 15, 4, 7, and 3. The role of the school and its collaborative methodology, the environment, and the mass media as key agents in the development of motivations and interests linked to sustainability.

\#Cluster 2: items 13, 14, 10, and 11. Importance of extracurricular actions to promote EfS and pro-environmental attitudes in students.

\#Cluster 3: items 6, 9, 8, 1, 2, and 5. Promotion of sustainable values, especially in children.

Finally, taking into account the response clusters according to the means obtained for both instruments (ex_ante evaluation questionnaire and change evaluation scale), we can highlight with respect to the change evaluation scale that there is an item with the maximum value and unanimity in the responses $\left(M_{e}=5.00\right)$. This item is related to the idea that EfS can positively influence the training of a citizenry committed to the environment (Figure 20). 


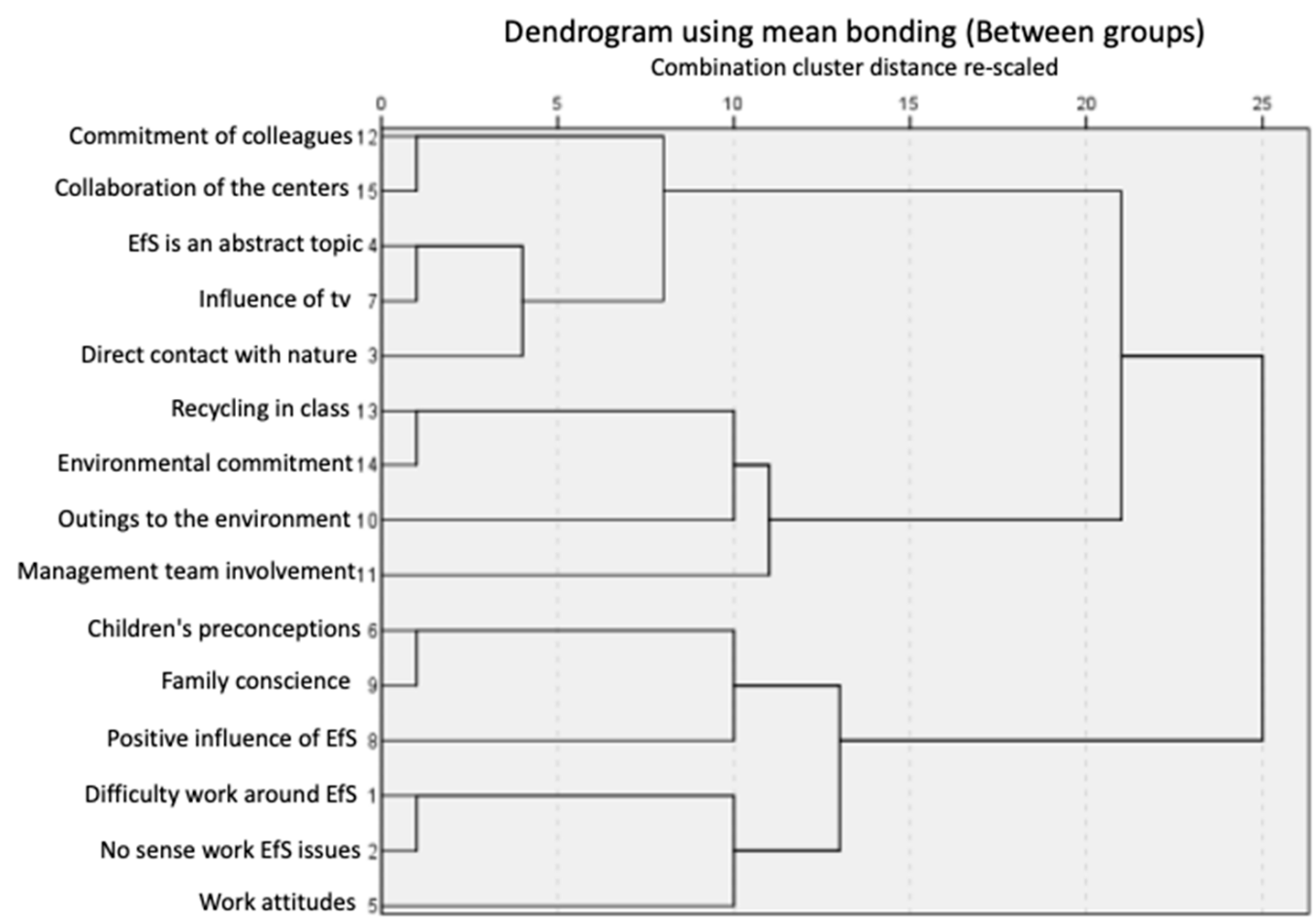

Figure 19. Dendrogram. Change evaluation scale.

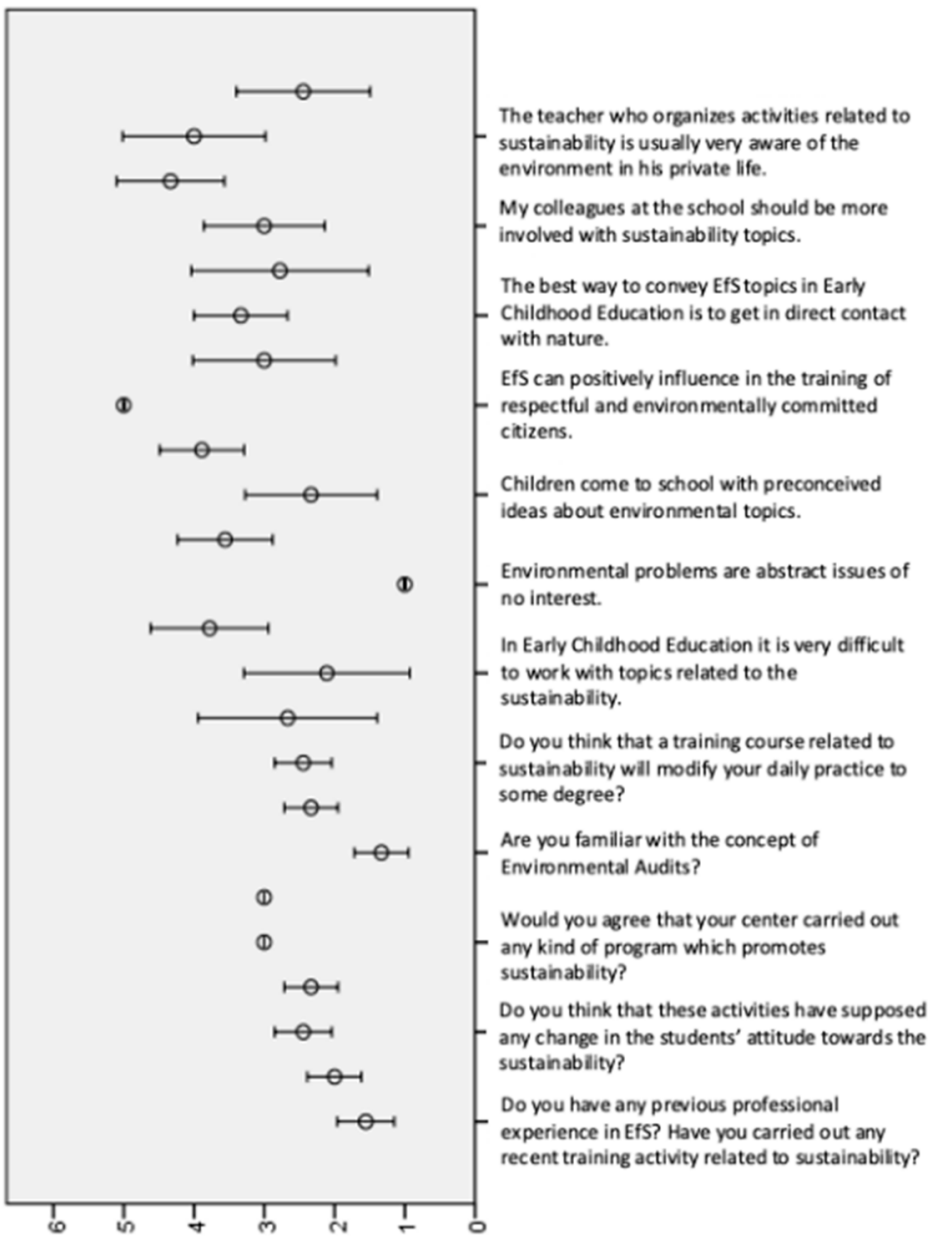

Figure 20. Average of responses (change evaluation scale). 
In general, the responses to the scale are placed with a high degree of agreement except for those items that are negative and where obtaining a high disagreement is depicted as positive, such as: "Environmental problems are abstract issues of no interest" $\left(\mathrm{M}_{\mathrm{e}}=1.00\right)$.

In general terms, these responses have allowed us to make the following aspects visible as strengths and weaknesses (Figure 21) to consider in order to outline the collaborative training action in Phase 2.

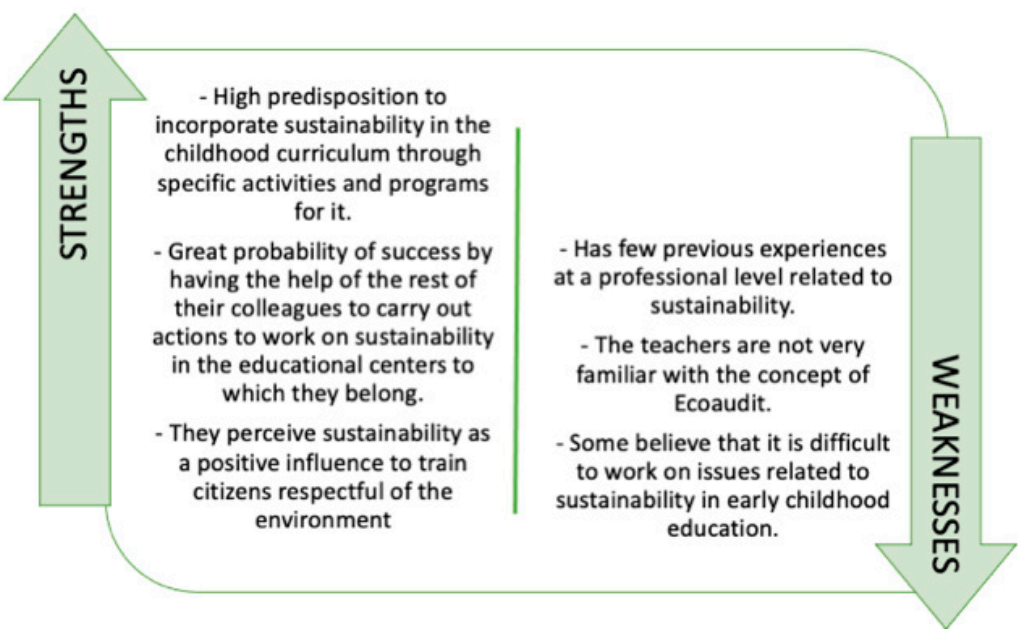

Figure 21. Strengths and weaknesses detected in Phase 1: Diagnosis of needs. Prepared by the authors.

\subsection{Results Derived from Phase 2: Design of the Strategic Plan}

In Phase 2, the collaborative training action was designed where the participating teachers from early childhood schools participated were advised by the work commission made up of the Granada Educa Foundation staff, by experts from the research group of the University of Granada, and by speakers who participated in the different work sessions. The objective of this training action was to train teachers in the acquisition of competences to work on sustainability with young students.

The design of this training action has been generated from a model of participatory reflection based on the demands expressed by the teachers in the previous phase. Through different work sessions, the final program was designed. Figure 22 depicts the triptych used by the organising entity to disseminate the designed CAR program.

This CAR program was divided in five sessions of three hours each, addressing the most appropriate content to minimise weaknesses and maximise the strengths that the teaching community manifested in the diagnostic phase (Table 7).

Table 7. Work sessions and contents of the training course in competencies related to sustainability for early childhood education teachers. Prepared by the authors.

\begin{tabular}{cc}
\hline Work Sessions & Contents \\
\hline $\begin{array}{c}\text { Session 1: Introduction to EfS } \\
\text { Session 2: Experiences and programs } \\
\text { that work on EfS }\end{array}$ & $\begin{array}{c}\text { Course presentation. Education for } \\
\text { sustainability: rationale. }\end{array}$ \\
Session 3: Immersion in the nature & $\begin{array}{c}\text { Environmental Education classroom activity: "How to } \\
\text { didactic use of recovery material. } \\
\text { Session 4: Inter-Centres Eco-Audit }\end{array}$ \\
develop a didactic itinerary". \\
Carrying out an eco-audit in an early childhood \\
school: Learning from practice. \\
Innovative experiences in EfS II.
\end{tabular}




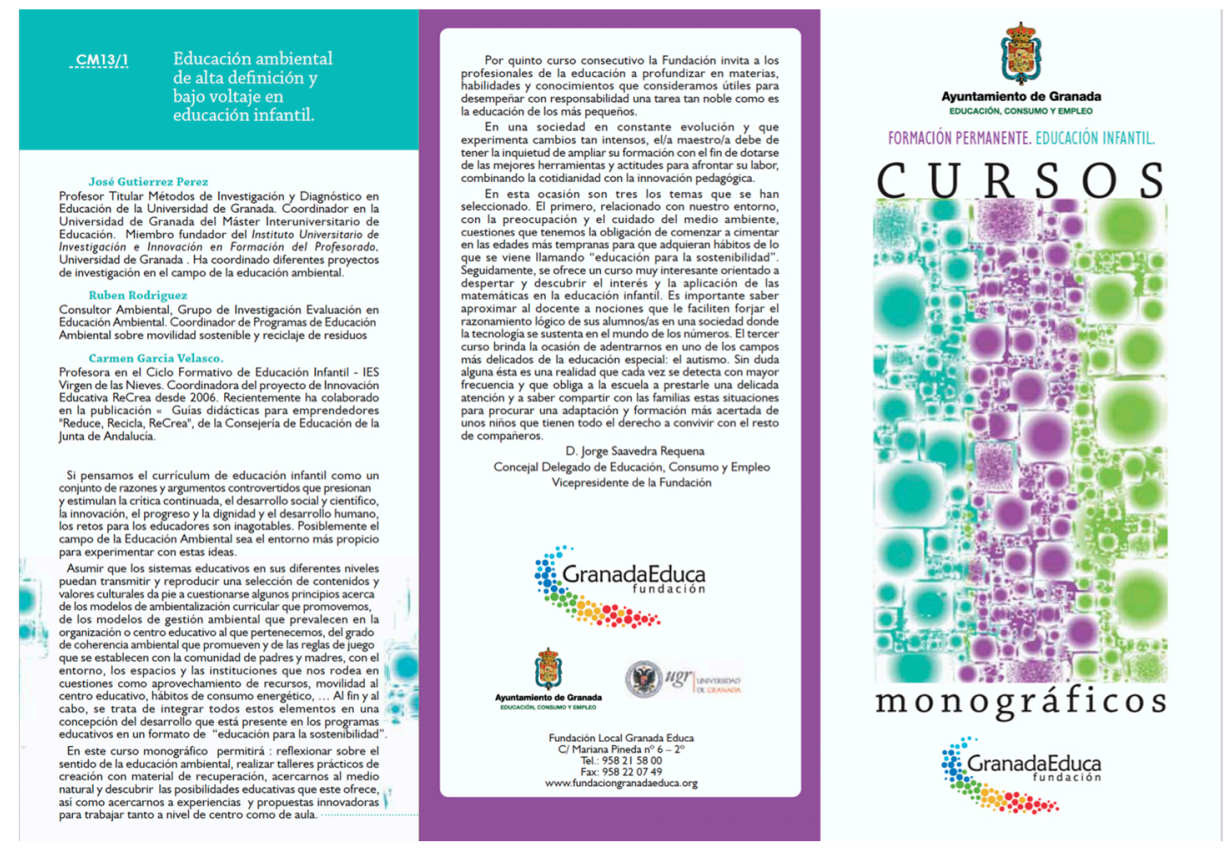

Figure 22. Triptych of the CAR program designed in Phase 2.

\subsection{Results Derived from Phase 3: Implementation of the Program}

Once the Inter-Centre Eco-Audit was carried out by the groups of participating teachers who became auditors, a pooling of the weaknesses found by each group in each of the assigned categories was carried out. Through a participatory process in which all the groups interacted at the same time, a brainstorming was carried out where the participants made their proposals for improvement to mitigate the weaknesses that they highlighted in each of the analysis categories (Table 8).

Table 8. Results of the Inter-Centre Eco-Audit carried out in an early childhood school.

\begin{tabular}{|c|c|c|}
\hline \multicolumn{3}{|r|}{ WATER } \\
\hline & Weaknesses & Improvement proposals \\
\hline $\begin{array}{l}- \\
-\end{array}$ & $\begin{array}{l}\text { Rainwater is not collected. } \\
\text { There are traditional taps in the students' bathrooms. } \\
\text { Low pressure from the drains. }\end{array}$ & $\begin{array}{ll}\text { - } & \text { Installation of new taps. } \\
\text { - } & \text { Install tanks to collect rainwater. }\end{array}$ \\
\hline \multicolumn{3}{|c|}{ WASTE MATERIAL } \\
\hline & Weaknesses & Improvement proposals \\
\hline $\begin{array}{l}- \\
-\end{array}$ & $\begin{array}{l}\text { Easy access for students to batteries. } \\
\text { Missing battery and plastic containers. } \\
\text { No separation of organic waste is done. } \\
\text { They don't use recycled toilet paper. } \\
\text { In the kitchen or in the garden, there are no waste } \\
\text { separation containers. } \\
\text { Only paper is recycled. }\end{array}$ & $\begin{array}{l}\text { - Request plastic containers from the town hall near the centre to } \\
\text { dispose the accumulated waste. } \\
\text { - } \quad \text { Request a battery container to place it in the school. } \\
\text { - Installation of buckets for the separation of waste in the kitchen. }\end{array}$ \\
\hline \multicolumn{3}{|r|}{ ENERGY } \\
\hline & Weaknesses & Improvement proposals \\
\hline $\begin{array}{l}- \\
- \\
-\end{array}$ & $\begin{array}{l}\text { Fluorescent lighting. } \\
\text { The windows do not have thermal insulation. } \\
\text { Non-renewable energy. } \\
\text { There are no rules agreed by the educational team on } \\
\text { the use of electronic devices (Action Protocol). }\end{array}$ & $\begin{array}{ll}\text { - } & \text { Install light sensors (corridors, bathrooms, etc.). } \\
\text { - } & \text { Install solar panels.- Replacing standard light bulbs with } \\
\text { low-consumption ones. } \\
\text { - } \quad \text { Replacement of kitchen appliances with more efficient ones. } \\
\text { - } \quad \text { Changes in consumption habits. }\end{array}$ \\
\hline
\end{tabular}


These weaknesses and proposals for improvement guide the more immediate actions to be carried out in the participating centres to generate a much more sustainable management model. From the approaches of this Inter-Centre Eco-Audit, it was revealed how the water and energy control and saving systems, as well as addressing the control of material waste, continue to be pending subjects in early childhood schools.

Addressing these problems will consolidate a much more sustainable management model that will have repercussions on committed management models at educational, social, economic, and environmental levels.

\subsection{Results Derived from the Evaluation of Results. Impact of Training Program}

\subsubsection{Results Derived from the Interview}

When analysing the interviews carried out with the teachers once the CAR program has been carried out, the effect that the program has had on the participants is revealed, as well as the impact it has had on the management models and curriculum development of sustainability in all teachers of the centres involved (participating or not in the CAR program).

\section{- Sustainable management model}

It is important to highlight in this category, considering the contributions of the participants, that the 'energy' subcategory is the most outstanding, as it includes $46.6 \%$ of the contributions. It is followed by the 'waste material' subcategory with $34.9 \%$ of the comments and the 'water' subcategory with $18.3 \%$, which is the least developed according to the arguments of the participants (Figure 23).

If we make a detailed analysis of the contributions of participants according to the units of analysis of each subcategory, it is possible to see how the percentage of presence of such contributions is balanced among all units of analysis with about 10-12 contributions in each one of them and each subcategory having a representation that ranges between $7.9 \%$ and $9.5 \%$ (Table 9 ).

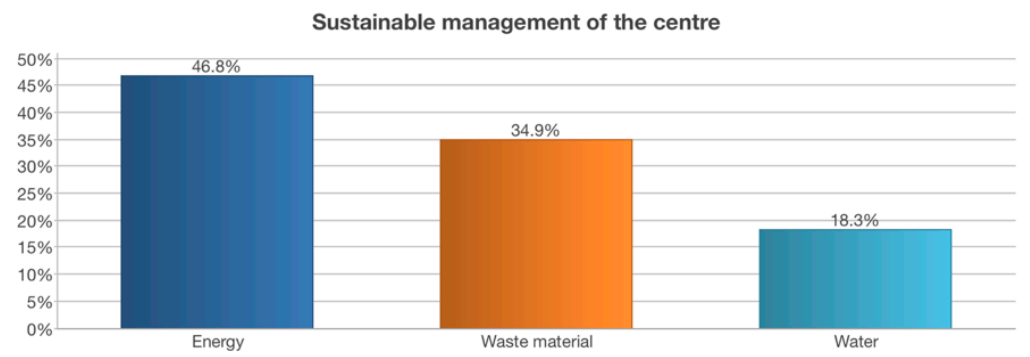

Figure 23. Percentage of presence—subcategories—sustainable management model.

Table 9. Percentage of presence—analysis units (sustainable management model).

\begin{tabular}{|c|c|c|c|}
\hline Subcategory & Analysis Units & Frequency & Percentage \\
\hline \multirow{5}{*}{$1^{\circ}$ Energy } & Energy saving & 12 & $9.5 \%$ \\
\hline & Hot water production & 12 & $9.5 \%$ \\
\hline & Window insulation & 12 & $9.5 \%$ \\
\hline & Solar panels & 12 & $9.5 \%$ \\
\hline & Lighting & 11 & $8.7 \%$ \\
\hline \multirow{4}{*}{$2^{\circ}$ Waste material } & Use bins & 12 & $9.5 \%$ \\
\hline & Waste separation & 12 & $9.5 \%$ \\
\hline & Surplus control (food) & 10 & $7.9 \%$ \\
\hline & Kitchen waste & 10 & $7.9 \%$ \\
\hline \multirow{2}{*}{$3^{\circ}$ Water } & Savings systems & 12 & $9.5 \%$ \\
\hline & Irrigation systems & 11 & $8.7 \%$ \\
\hline \multicolumn{2}{|c|}{ Sum } & 126 & $100 \%$ \\
\hline \multicolumn{4}{|c|}{ High Priority Management } \\
\hline \multicolumn{4}{|c|}{ Second Priority Management } \\
\hline
\end{tabular}


These data have made it possible to establish a general order of priority in the three main categories of centre management: firstly, those related to energy; secondly, those related to waste management; and thirdly, those related to water. Regarding the subcategories, each centre has taken as a reference the general ranking of theoretical priorities (arranged in two levels, Green of high priority and Yellow of second priority), although in practice, each centre has adopted intervention decisions adapted to the singularity, contextual characteristics, feasibility, and opportunity for implementation. Teachers have taken this global ranking as a reference, which establishes shared priorities for all centres on issues whose solution does not directly depend on their ability to act as teachers. Even so, their consensus has made it possible to adopt external measures linked to decisions of the Granada Educa Foundation in relation to energy or municipal decisions related to the collection of solid waste classified by the need to undertake actions directed in the first place to three main categories.

Among the most outstanding contributions that show the changes and improvements at the sustainable management level of centres participating in the CAR program, the following stand out (Figure 24).

In general, there is a high level of responsibility and commitment in the centres to generate a sustainable management model, especially in the categories analysed. It is confirmed that this commitment is generating actions and proposals to improve the management of irrigation systems, water and energy saving, and waste control, among others.

\section{- Curricular innovation}

It is important to highlight in this category, considering the contributions of the participants, that the 'EfS Transversality and Practice' subcategory is the most outstanding with $57.6 \%$ of the contributions. It is followed by the 'Collaborative Work' and 'Social Climate' subcategories with $24.5 \%$ and $17.9 \%$ of the comments respectively (Figure 25).

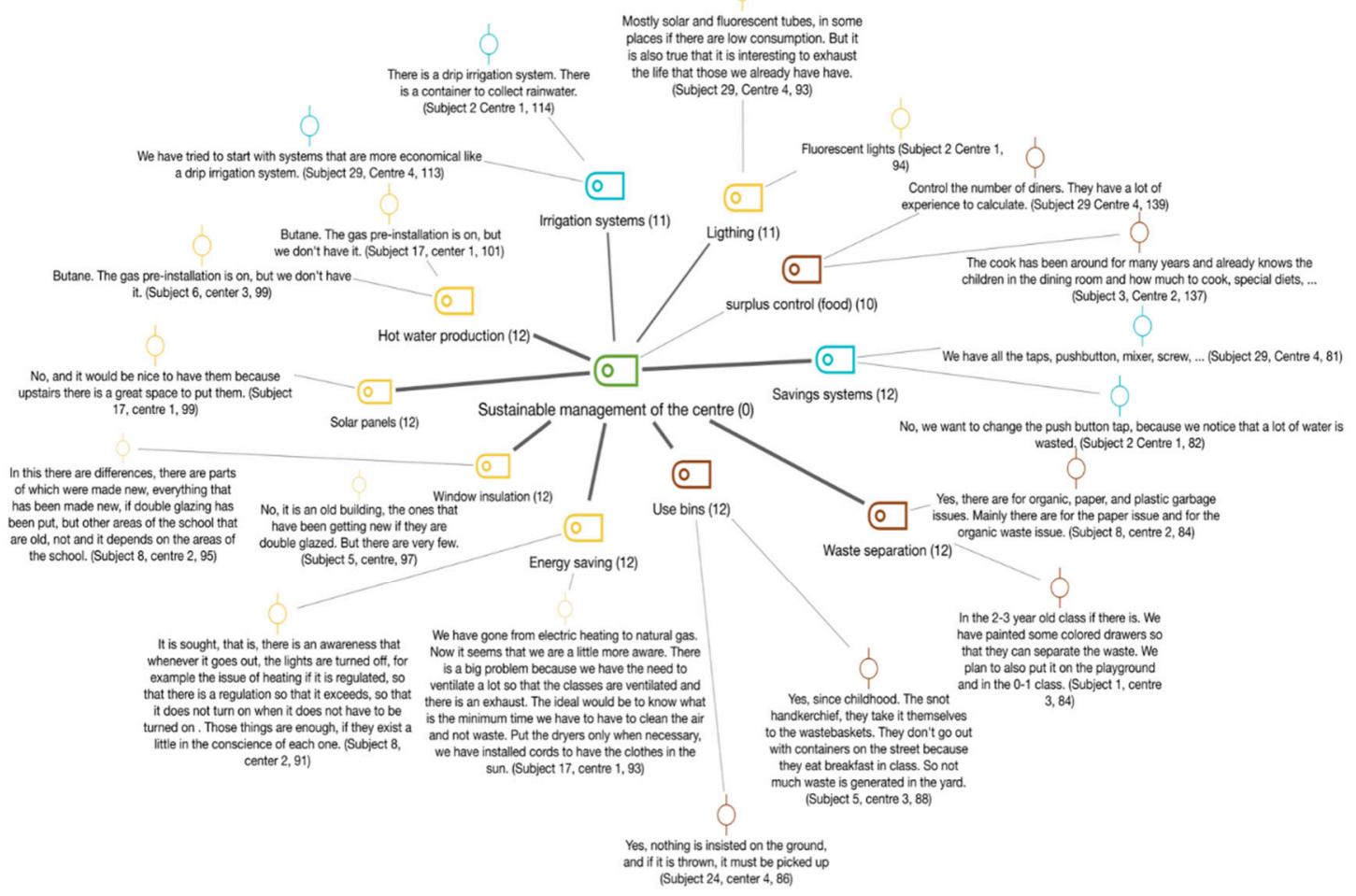

Figure 24. Contributions related to the most relevant units of analysis (sustainable management model). 


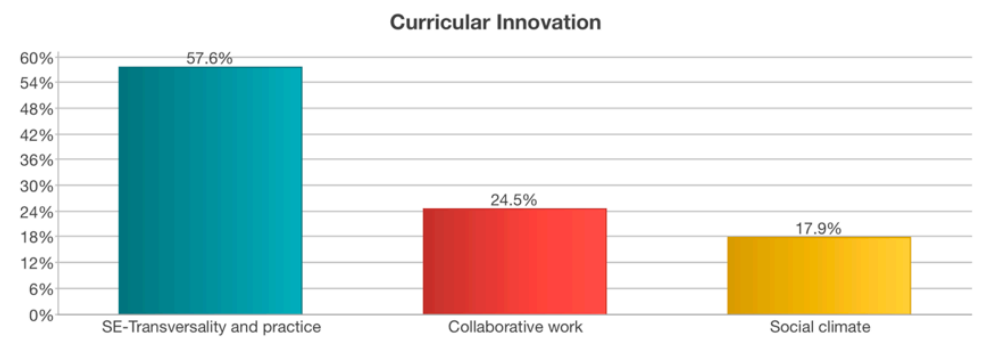

Figure 25. Percentage of presence-subcategories—curricular innovation.

If we make a detailed analysis of the contributions of the participants according to the units of analysis of each subcategory, it is possible to see how one unit of analysis stands out compared to the rest, with 70 contributions (13.6\% representation). This unit is 'EfS Research and Innovation in the Classroom'. Its degree of presence shows how the program has had a multiplying effect on the commitment generated in the teachers of the participating centres and from there, a shared responsibility has been generated to accommodate the methodologies, adapt the contents, and favour the development of transformation and action competences linked to sustainability in its students through the design of research and innovation proposals in the classroom.

This unit of analysis is followed in representation by 'Installations and Equipment EfS' (42 contributions, $8.2 \%$ representation), which is also closely related to the analysis category 'sustainable management model'. This block of contributions corroborates the interconnection that exists between the teaching practice and the management model and the impact and projection that the teaching work has on the sustainability of the infrastructures and facilities of the centre (Table 10).

Table 10. Percentage of presence-analysis units (curricular innovation).

\begin{tabular}{|c|c|c|c|}
\hline Subcategory & Analysis Unit & Frequency & Percentage \\
\hline \multirow{3}{*}{ Social climate } & Social climate assessment & 30 & $5.8 \%$ \\
\hline & Promoted values & 30 & $5.8 \%$ \\
\hline & Attitudes and behaviours & 32 & $6.2 \%$ \\
\hline \multirow{4}{*}{ Collaborative work } & Teamwork & 30 & $5.8 \%$ \\
\hline & Cooperative and experimental learning & 36 & $7.0 \%$ \\
\hline & Experiences, concerns, and wishes & 28 & $5.4 \%$ \\
\hline & Local problems & 32 & $6.2 \%$ \\
\hline \multirow{8}{*}{ EfS-Transversality and practice } & EfS diffusion & 30 & $5.8 \%$ \\
\hline & EfS and relationship with the environment & 31 & $6.0 \%$ \\
\hline & Healthy living practices & 32 & $6.2 \%$ \\
\hline & EfS research and innovation in the classroom & 70 & $13.6 \%$ \\
\hline & Interdisciplinary coordination & 30 & $5.8 \%$ \\
\hline & EfS in educational projects & 30 & $5.8 \%$ \\
\hline & Teachers aware of EfS & 31 & $6.0 \%$ \\
\hline & Installations and equipment for EfS & 42 & $8.2 \%$ \\
\hline & Sum & 514 & $100 \%$ \\
\hline
\end{tabular}

To address the relationship of the main themes (included in Table 10) with the water, waste, and energy curriculum, we show a modeling of some of these connections in Figure 26 that exemplify the integrated and non-fragmented approach of these curricular themes. In the following figure, you can see in detail the connections and specific links of 
each subject with the integrated curricular actions developed in the different educational centres. For example:

(1) Regarding water, we can see the link that connects "cooperative and experimental learning" with curricular innovation actions: "In the school garden, we plant carrots, lettuce, and beans in the appropriate the season. Now, we are learning about the issue of water, because they are experimenting with activities whose consequences are captured later" (Subject 30, Centre 4).

(2) Regarding energy, the teachers link this issue with the eco-school program: "When we have the cloisters and meetings, we talk about the eco-school. This year, we are working on energy and we have incorporated it at the curricular level in some of the subjects" (Subject 29, Centre 4).

(3) Regarding waste management, teachers link this action with the contents and activities of the classroom: "We use all kinds of plastic containers of all kinds, large, small, medium, containers, cans, cartons, rollers, everything. We use that. Now, we have done a workshop with trays. Also of yogurts... We use many elements of everyday life for activities" (Subject 16, Centre 3).

Among the most outstanding comments that highlight the changes and improvements at the level of curricular greening of the centres participating in the CAR program, the following stand out (Figure 26).

In general, the centres have a high level of responsibility and commitment to favor the greening of the curriculum and the development of action and transformation competences into sustainability in students. It is corroborated that this commitment is generating actions and proposals to improve the inclusion of the EfS in their teaching practice, addressing sustainability in the classroom from collaborative work, with a much more proactive social climate and from the development of sustainability competences. All this with a projection outside the classroom walls has an impact on a school model with much more sustainable infrastructure and equipment.

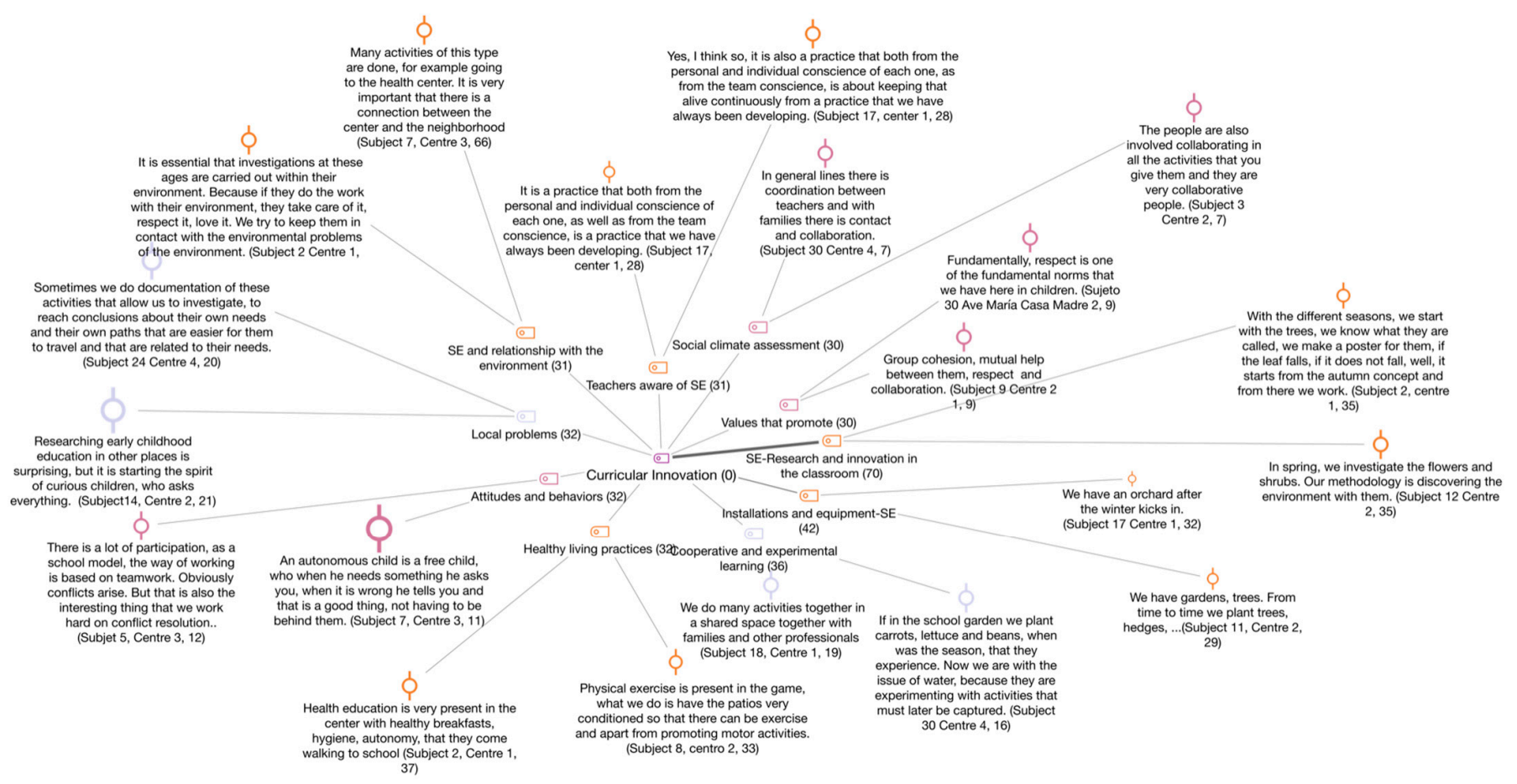

Figure 26. Contributions related to the most relevant units of analysis (curricular innovation). 


\subsubsection{Results Derived from the Evaluation Scale}

The data provided by the evaluation scale on the environmentalisation of early childhood education centres and their commitment to sustainability (Phase 4) have allowed us to evaluate the impact of the model of teacher education and training on sustainability, which has been presented throughout this document, since it offers information on the degree of satisfaction that early childhood education teachers have after the implementation of the CAR program with respect to the categories of analysis, from a general perspective.

The dimensions of analysis present in this scale have been the same as in the interview (EfS Transversality; Social Climate; Collaborative Work; Water; Energy and Waste Material), although taking into account the complexity of the category 'EfS Transversality and Practice', the items linked to this category were broken down into four: EfS Transversality, Practical EfS, EfS Diffusion, and School-Environment Relationship.

For the representation of this quantitative part, we have carried out a cluster analysis, measures of central tendency, as well as multivariate content classification using hierarchical cluster analysis through Ward Linkage in order to see how the items are grouped based on the responses of the interviewed subjects.

The dendrogram (Figure 27) shows us the existence of two clearly differentiated clusters, since we can observe how the items are grouped coinciding with the categories of analysis (sustainable management of the centre and curricular innovation).

On the one hand, we find cluster \#1, which groups the subcategories related to the sustainable management of the centre (water, waste material, and energy), which the subjects show moderate satisfaction with, as we can see in Figure 28, where the measures of central tendency show us that water and waste material have $M_{e}=3.00$ and energy has $\mathrm{M}_{\mathrm{e}}=4.00$ on a scale of 1-5. This is due to the low incidence that teachers have in making direct decisions regarding these aspects, since these are usually issues that are managed directly from the management of each centre or from the management of the foundation. As we have seen through their testimonies in the qualitative analysis, the subjects pointed out that changes must be made in some of the infrastructures to improve aspects related to water management, the separation of solid waste, and energy saving. However, despite these aspects, the teachers try to involve children in activities linked to the transmission of sustainable attitudes related to saving water, energy and solid waste management, instilling in them simple gestures such as turning off the lights when they are not necessary and relying on sunlight whenever possible; closing the taps when they are finished using them or generating the least possible solid waste using recycled material in their activities; among other initiatives. These are routines that children assimilate and internalise from a young age and that will make them future citizens committed to sustainability.

Cluster \#2 is related to the curricular innovation category and is composed of the following subcategories: Collaborative Work $\left(M_{e}=5.00\right)$; Social Climate $\left(M_{e}=5.00\right)$; EfS Transversality $\left(\mathrm{M}_{\mathrm{e}}=4.00\right)$; Practical EfS $\left(\mathrm{M}_{\mathrm{e}}=4.00\right)$; School-Environment Relationship $\left(\mathrm{M}_{\mathrm{e}}=4.00\right)$, and Diffusion $\left(\mathrm{M}_{\mathrm{e}}=4.00\right)$. In this cluster, the teachers interviewed have shown through the scores given to these items to have a greater satisfaction overall. This is due to the fact that they perceive this category as the one that is most related to their scope of action within the educational centre through the activities that they carry out with children in class. This fact is corroborated with the testimonies provided by the participants in the interviews where they make visible how they put in practice aspects related to sustainability in their daily practice through research and investigation activities or other specific activities such as outings to the surrounding environment to know the neighbourhood and the resources it offers them.

It should be noted that in the evaluation scale, in the items related to the 'EfS Transversality and Practice' category, the values are inverted with respect to the results of the qualitative analysis where it appeared as the category with the highest percentage of contributions from the teachers. Although on this scale its assessment is good $(\bar{x}=4.20)$, categories such as social climate $(\bar{x}=4.47)$ or collaborative work $(\bar{x}=4.70)$ appear ahead. This indicates that in this case, they do not perceive it as the most satisfactory category, 
because they think that enough is not done, and therefore, it is necessary to continue working on aspects related to sustainability. Ultimately, these results are closely related to the degree of commitment they have acquired. Their expectations are so high that they pursue excellence and, therefore, they show somewhat lower averages on the satisfaction scale than what was commented through the gathered testimonials.

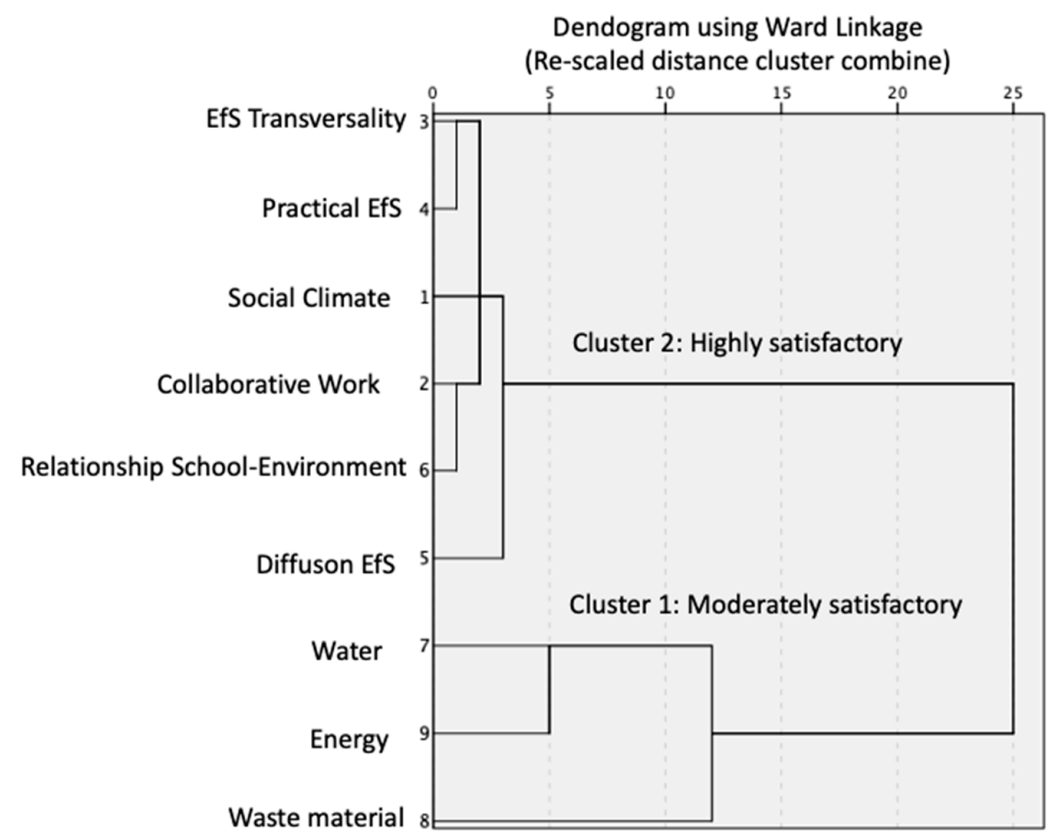

Figure 27. Dendrogram. Scale of satisfaction with the categories of the interview.

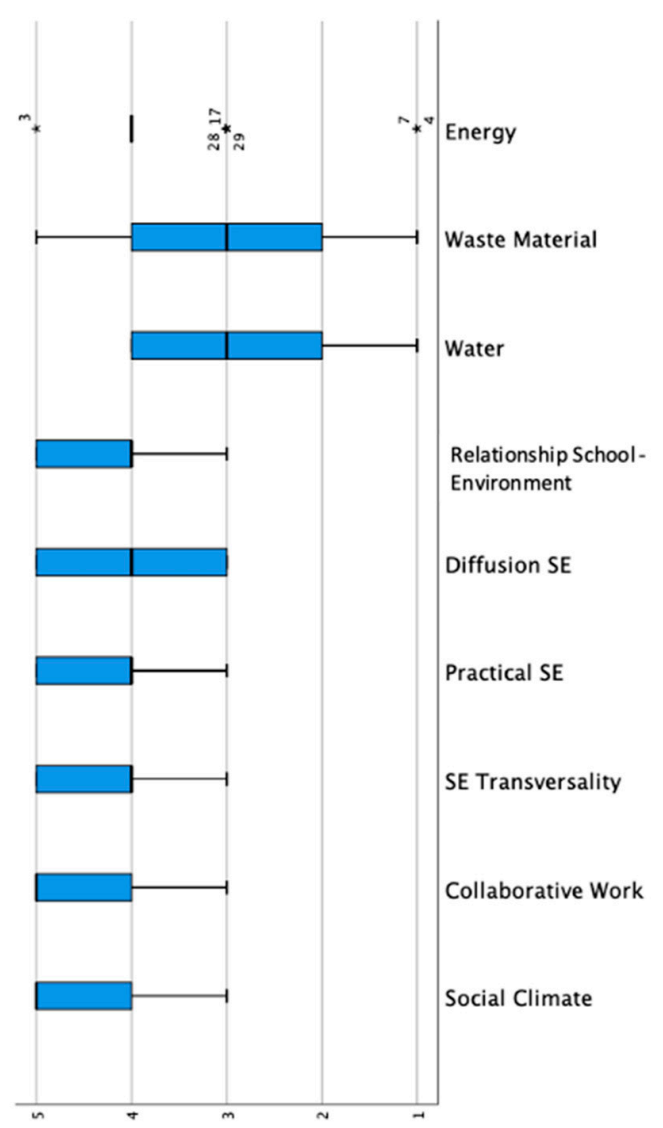

Figure 28. Measures of central tendency. Scale of satisfaction with the categories of the interview. Response scale ranges from 1 (Not satisfactory) to 5 (Highly satisfactory). ${ }^{*}=$ out-layer values. 


\section{Discussion and Conclusions}

The purpose of this research was the creation of a CAR model aimed at empowering the group of early childhood education teachers. The model has provided them with instruments that contribute to their professional development and the acquisition of action competences through a collaborative process with researchers in the field of sustainability. The model includes a sequence of coordinated work in four phases: (1) assessment of needs, (2) design of a collaborative training program, (3) implementation plan, and (4) final evaluation. This CAR sequence has made it possible for early childhood education teachers to assume the roles of participatory researchers and acquire environmental literacy competences. Evidence of these changes can be seen in the curricular innovation actions developed in the classroom and a greater involvement and commitment in tasks of distributive leadership and environmental management of the centre $[2,6]$.

At the beginning of the research, we were able to verify that many of the teachers were not aware that they were already applying different aspects of EfS in their daily practice, although their decision-making levels in the centre's environmental management processes could be improved. As the development of the collaborative training program progresses, we find that teachers are more involved in processes of reflection on their practice. The teachers of some centres exchange good practices with their peers from other schools, review their environmental habits, and discuss their commitments to curricular transformation, innovation, and environmental management of the centre [51,52]. They introduce more sustainable practices in their professional activity and develop interdisciplinary actions in their classrooms that involve a greater commitment of families and schoolchildren to the environmental problems of the neighbourhood and the centre. Aspects related to the acquisition of proximity products in school kitchens are critically questioned, the models and habits of movement, mobility, and access to the centre are discussed, and they review the use of water and energy and propose recycling and waste management actions [71-73]. In general, there is a progressive increase in the environmental awareness of the teachers involved in the CAR process after a continuous period of coordinated work.

In the light of the quantitative data and qualitative evidence evaluated, we can verify the impact that the training program has generated on the participants as well as the changes caused in the decision-making models more oriented toward distributive leadership schemes, where decisions about the environmental management of the centre arise from the bottom up, and it is the teachers themselves who assume responsibilities in different areas that affect the sustainable transformation of the centre [11]. The study shows obstacles and limitations to implement changes in this dimension linked to a low capacity for direct influence on the management of resources, infrastructures, and other factors of the daily life of the centre that are outside the transforming capacity of the actions of the teaching staff. Likewise, there is a certain difficulty in intervening in complex environmental problems that require different levels of participation in decision-making and involve multiple agents in solving problems and adopting strategic measures $[83,85]$.

As the carried out eco-audits have shown, in the majority of the studied cases, the most notable weaknesses are focussed on aspects related to energy, water, and waste management, where efforts should be increased to improve results. Regarding aspects related to water management, it is necessary to make improvements in the facilities, which translates into an extra expense that the centre must face through decisions of the institution's staff, according to the organisational model of foundation. Regarding the management of waste material, the main problem is that some centres do not have nearby containers for the management of garbage and other solid waste, which is an inconvenience since they would like to manage them properly, but the decision is in the hands of neighbourhood leaders, the companies that organise waste collection, and the City's Environment Department. In the case of energy, this environmental dimension also entails changes that involve an economic outlay, such as replacing existing lighting with low-consumption light bulbs, insulation for windows, and incorporating the use of 
renewable energy such as solar power, which requires medium-term budget planning and the consent of economic decision makers.

Teachers propose to mitigate these deficiencies, raising awareness among their students from the activities and proposals that are made in the classroom on a day-to-day basis. This is done through simple routines such as turning off the lights when it is not necessary to use them, being careful to not leaving the taps open after using them, reusing the material they employ to do the projects and activities, or not generating unnecessary solid waste by means of, for example, the reduction of snack packages and promoting the consumption of fruit every day instead.

We have seen a great willingness in the teachers to address EfS issues at an early age. This has generated a multiplier effect of the training program that has favoured professional development in the centres and has involved families, staff, and other agents of the educational community. The teachers that are most involved in the collaborative training program have served as a driving force, energising other colleagues from non-participating centres, generating in them interest in incorporating aspects related to sustainability in the activities they carry out in class [62].

We have also observed a more positive assessment of those aspects related to curricular innovation. Teachers feel they can directly influence aspects such as the social climate or teamwork as well as include EfS in a transversal way, encouraging the participation of families and other external agents related to the environment of the centre as well as recovering spaces and green areas in and around the centre to develop EfS projects linked to reality and the territorial context in which they are located [92].

All these aspects do have a fairly high level of satisfaction among teachers. They are committed to the curricular greening and the integration of natural and urban territory in their classroom work. This is appreciated and verified in the different programs they promote, in which the environmental dimension is present, and in the different activities they carry out in which they tend to adopt inter and multidisciplinary methodologies (such as the systematic work carried out in most centres where recycled and/or reused elements are employed), as well as including families and the rest of the educational community in the dynamics of the centre $[37,38,47,75,83,101]$.

\section{Future Research}

Regarding future lines of work, we consider as an objective the consolidation of our participatory action research model and its extrapolation to other contexts allowing us to carry it out including other work groups, so that we can achieve, through awareness, the dissemination and training in sustainability of early childhood education teachers who feel secure when facing the implementation of the EfS in the curriculum, as well as the important task of training the citizens of the future. It would be interesting to make a document proposal that shows how to carry out a complete Eco-Audit process in educational centres with the aim of developing a roadmap and guidelines to follow to correct weaknesses and enhance the strengths detected. The aim is to carry out a mixed approach in which the effectiveness and efficiency of the programs and activities in progress are analysed and a strategic reorientation of them that allows us to adopt optimisation decisions for an improved coordinated can be carried out.

Finally, in response to the question that we raised at the beginning of this article, "Can early childhood teachers assimilate the three dimensions of sustainability (management, teaching, and research/innovation)?", we consider that it is utterly important to value and empower the profession of early childhood teachers, as they have an important task that often goes unnoticed. Through participation in action-research models such as the one proposed in this document, teachers become reflective agents of their own practice, questioning at all times how to improve those aspects with which they feel completely satisfied and looking for innovative ways to improve their work, such as the acquisition of new competences that adjust to the new challenges demanded by the new generations. 
Author Contributions: Conceptualisation, A.L-A.; M.F.P.-V. and J.G.-P.; methodology, A.L.-A.; M.F.P.-V. and M.T.P.-L.; software, A.L.-A.; M.F.P.-V. and J.G.-P.; validation, J.G.-P. and M.T.P.-L.; formal analysis, A.L.-A.; M.F.P.-V.; J.G.-P. and M.T.P.-L.; investigation, A.L.-A. and J.G.-P.; resources, A.L.-A. and M.F.P.-V.; data curation, A.L.-A.; M.F.P.-V.; J.G.-P. and M.T.P.-L.; writing-original draft preparation, A.L.-A.; M.F.P.-V.; writing—review and editing, A.L.-A.; M.F.P.-V.; J.G.-P. and M.T.P.-L.; visualisation, A.L.-A. and M.T.P.-L.; supervision, A.L.-A. and M.F.P.-V.; project administration, A.L.-A. and J.G.-P.; funding acquisition, M.F.P.-V., J.G.-P. and M.T.P.-L. All authors have read and agreed to the published version of the manuscript.

Funding: This research is part of the collaborative project: "Sustainability in Higher Education: Evaluation of the scope of the 2030 Agenda in curriculum innovation and teacher professional development in Andalusian Universities", Ref. B-SEJ-424-UGR18.

Institutional Review Board Statement: This study does not require ethical approval.

Informed Consent Statement: Informed consent was obtained from all subjects involved in the study.

Data Availability Statement: Data available on request due to restrictions (ethical).

Acknowledgments: This research has been possible thanks to the collaboration of the teachers of the Early Years Schools of the Granada-Educa Foundation (former Municipal Board of Nursery Schools), professionals always open to any innovative process that affects their training, that motivates their students and impact in improving your schools. A special thanks to Mercedes Blasi Vélez and Juan Quesada Gámiz, responsible for the Psychopedagogical Team, for their capacity for distributive leadership and their way of understanding pedagogical renewal in the field of Early Childhood Education.

Conflicts of Interest: The authors declare no conflict of interest.

\section{References}

1. Moreno-Vera, J.R.; Ponsoda-López de Atalaya, S.; López-Fernández, J.A.; Blanes-Mora, R. Holistic or Traditional Conceptions of Heritage among Early-Childhood and Primary Trainee Teachers. Sustainability 2020, 12, 8921. [CrossRef]

2. Rodríguez-Marín, F.; Puig-Gutiérrez, M.; López-Lozano, L.; Guerrero-Fernández, A. Early Childhood Preservice Teachers' View of Socio-Environmental Problems and Its Relationship to the Sustainable Development Goals. Sustainability 2020, $12,7163$. [CrossRef]

3. Melis, C.; Wold, P.-A.; Bjørgen, K.; Moe, B. Norwegian Kindergarten Children's Knowledge about the Environmental Component of Sustainable Development. Sustainability 2020, 12, 8037. [CrossRef]

4. Wrigth, T. The Evolution of Sustainability Declarations in Higher Education. In Higher Education and the Challenge of Sustainability: Problematics, Promise, and Practice; Corcoran, P., Wals, A., Eds.; Kluwer Academic Publishers: Dordrecht, The Netherlands, 2004.

5. Barth, M.; Michelsen, G.; Rieckmann, M.; Thomas, I. Routledge Handbook of Higher Education for Sustainable Development; Routledge: Abigdon on Thames, UK, 2018.

6. Leal, W. Encyclopedia of Sustainability in Higher Education; Springer International Publishing: Cham, Switzerland, 2019.

7. MacNiff, J. Action Research All You Need to Know; Sage: London, UK, 2017.

8. Pérez de Albéniz-Garrote, G.; Medina-Gómez, M.B. The Innovative and Research Professional Identity of Future Early Years and Primary School Teachers and Their Relationship with Psychological Well-Being. Sustainability 2020, 12, 8593. [CrossRef]

9. Marouli, C.; Duroy, Q. Reflections on the Transformative Power of Environmental Education in Contemporary Societies: Experience from Two College Courses in Greece and the USA. Sustainability 2019, 11, 6465. [CrossRef]

10. García-Carrión, R.; Padrós Cuxart, M.; Alvarez, P.; Flecha, A. Teacher Induction in Schools as Learning Communities: Successful Pathways to Teachers' Professional Development in a Diverse School Serving Students Living in Poverty. Sustainability 2020, 12, 7146. [CrossRef]

11. Pérez-Garcias, A.; Tur, G.; Darder Mesquida, A.; Marín, V.I. Reflexive Skills in Teacher Education: A Tweet a Week. Sustainability 2020, 12, 3161. [CrossRef]

12. Cigala, A.; Venturelli, E.; Bassetti, M. Reflective Practice: A Method to Improve Teachers' Well-Being. A Longitudinal Training in Early Childhood Education and Care Centers. Front. Psychol. 2019, 10, 2574. [CrossRef]

13. Marcos-Merino, J.M.; Corbacho-Cuello, I.; Hernández-Barco, M. Analysis of Sustainability Knowingness, Attitudes and Behavior of a Spanish Pre-Service Primary Teachers Sample. Sustainability 2020, 12, 7445. [CrossRef]

14. Poza-Vilches, M.F.; Gutiérrez-Pérez, J.; Pozo-Llorente, M.T. Quality Criteria to Evaluate Performance and Scope of 2030 Agenda in Metropolitan Areas: Case Study on Strategic Planning of Environmental Municipality Management. Int. J. Environ. Res. Public Health 2020, 17, 419. [CrossRef]

15. Melnik, H.; Darling-Hammond, L.; Leung, M.; Yun, C.; Schachner, A.; Plasencia, S.; Ondrasek, N. Reopening Schools in the Context of COVID-19: Health and Safety Guidelines from other Countries. Learning Policy Institute [Blog]. 2020. Available online: https: / learningpolicyinstitute.org/product/reopening-schools-covid-19-brief (accessed on 20 November 2020). 
16. Osmond-Johnson, P.; Campbell, C.; Pollock, K. Moving foward in the Covid-19 Era: Reflections for Canadian Education. EdCan Network [Blog]. 2020. Available online: https:/ / www.edcan.ca/articles/moving-forward-in-the-covid-19-era/ (accessed on 20 November 2020).

17. Blyth, A.; Velissaratou, J. How do We Re-Open Schools after the Coronavirus Pandemic? OECD Education and Skills Today. 2020. Available online: https:/ / oecdedutoday.com/how-re-open-schools-after-coronavirus/ (accessed on 20 November 2020).

18. Basilaia, G.; Dgebuadze, M.; Kantaria, M.; Chokhonelidze, G. Replacing the classic learning format universities as an immediate response to the COVID-19 virus infection in Georgia. Int. J. Res. Appl. Sci. Eng. Technol. 2020, 8, 101-108. [CrossRef]

19. Liguori, E.W.; Winkler, C. From offline to online: Challenges and opportunities for entrepreneurship education following the COVID-19 pandemic. Entrep. Educ. Pedagog. 2020, 3, 346-351. [CrossRef]

20. Suárez, L.; Asunción, M.; Rivera, L.; Pratesi, I.; Galaverni, M.; Antonelli, M. Pérdida de Naturaleza y Pandemias: Un Planeta Sano Por la Salud de la Humanidad; WWF: Madrid, Spain, 2020. Available online: https:/ /d80g3k8vowjyp.cloudfront.net/downloads/ naturaleza_y_pandemias_wwf.pdf (accessed on 20 November 2020).

21. Leal-Filho, W.; Brandli, L.L.; Lange-Salvia, A.; Rayman-Bacchus, L.; Platje, J. COVID-19 and the UN Sustainable Development Goals: Threat to Solidarity or an Opportunity? Sustainability 2020, 12, 5343. [CrossRef]

22. Welzer, H. Guerras Climáticas. Por qué Mataremos (y Nos Matarán) en el Siglo XXI; Katz Editores: Madrid, Spain, 2020.

23. Caride, J.A.; Meira, P.A. La educación ambiental en los límites, o la necesidad cívica y pedagógica de respuestas a una civilización que colapsa. Pedagog. Soc. Rev. Interuniv. 2020, 3, 21-34. [CrossRef]

24. Sousa-Santos, B. La Cruel Pedagogía del Virus; Clacso: Buenos Aires, Argentina, 2020.

25. George, M.L. Effective teaching and examination strategies for undergraduate learning during COVID-19 school. J. Educ. Technol. Syst. 2020, 49, 23-48. [CrossRef]

26. Girik, A.M.D. Is the online learning good in the midst of Covid-19 Pandemic? The case of EFL learners. J. Sinestesia 2020, 10, 1-8.

27. Lassoued, Z.; Alhendawi, M.; Bashitialshaaer, R. An Exploratory Study of the Obstacles for Achieving Quality in Distance Learning during the COVID-19 Pandemic. Educ. Sci. 2020, 10, 232. [CrossRef]

28. UNESCO. Distance Education in the Corona Virus Pandemic. 2020. Available online: https://en.unesco.org/covid19/ educationresponse (accessed on 20 November 2020).

29. Khalaf, Z.N. Corona Virus and Digital Equality in Tele-Teaching in Emergency Situations. New Education Blog. 2020. Available online: https:/ / www.new-educ.com/ (accessed on 20 November 2020).

30. UN. Transforming our world: The 2030 Agenda for Sustainable Development. 2015. Available online: https: / / sustainabledevelopment. un.org/post2015/transformingourworld (accessed on 20 November 2020).

31. Martin, A. How to Optimize Online Learning in the Age of Coronavirus (COVID-19): A 5-Point Guide for Educators. 2020. Available online: https://www.researchgate.net/publication/339944395_How_to_Optimize_Online_Learning_in_the_Age_ of_Coronavirus_COVID-19_A_5-Point_Guide_for_Educators (accessed on 20 November 2020).

32. Guerriero, S. Pedagogical Knowledge and the Changing Nature of the Teaching Professional; OECD: Paris, France, 2017.

33. Iwaniec, J.; Curdt-Christiansen, X.L. Parents as Agents: Engaging Children in Environmental Literacy in China. Sustainability 2020, 12, 6605. [CrossRef]

34. Milfont, T.; Poortinga, W.; Sibley, C.G. Does having children increase environmental concern? Testing parenthood effects with longitudinal data from the New Zealand Attitudes and Values Study. PLoS ONE 2020, 15, e0230361. [CrossRef]

35. Wang, W.; Curdt-Christiansen, X.L. Lost in translation: Parents as medium translators in intergenerational transmission. Curr. Issues Lang. Plan. 2020, 1-21. [CrossRef]

36. Loebach, J.; Cox, A. Tool for Observing Play Outdoors (TOPO): A New Typology for Capturing Children's Play Behaviors in Outdoor Environments. Int. J. Environ. Res. Public Health 2020, 17, 5611. [CrossRef] [PubMed]

37. Eugenio-Gozalbo, M.; Aragón, L.; Ortega-Cubero, I. Gardens as science learning contexts across educational stages: Learning assessment based on students' graphic representations. Front. Psychol. 2020, 11, 2226. [CrossRef] [PubMed]

38. Spano, G.; D’Este, M.; Giannico, V.; Carrus, G.; Elia, M.; Lafortezza, R.; Panno, A.; Sanesi, G. Are Community Gardening and Horticultural Interventions Beneficial for Psychosocial Well-Being? A Meta-Analysis. Int. J. Environ. Res. Public Health 2020, 17, 3584. [CrossRef] [PubMed]

39. García-González, E. ¡Urgente, urgente! Re-naturalicemos la escuela en tiempos de pandemia. Rev. Educ. Ambient. Sostenibilidad 2020, 2, 1501. [CrossRef]

40. López-Alcarria, A.; Gutiérrez-Pérez, J.; Poza-Vilches, F. Preschool Education Professionals as Mediators of Environmental Health Education. Procedia-Soc. Behav. Sci. 2014, 132, 639-646. [CrossRef]

41. Poza-Vilches, M.F.; Gutiérrez-Pérez, J.; López-Alcarria, A. Greening Spanish primary schools: Students and teachers attitudes to centres committed to sustainability. SHS Web Conf. 2016, 26, 01043. [CrossRef]

42. Alba-Hidalgo, D.; Benayas, J.; Gutiérrez-Pérez, J. Towards a definition of environmental sustainability evaluation in higher education. High. Educ. Policy 2018, 31, 447-470. [CrossRef]

43. Abubakar, I.R.; Aina, Y.A.; Alshuwaikhat, H.M. Sustainable Development at Saudi Arabian Universities: An Overview of Institutional Frameworks. Sustainability 2020, 12, 8008. [CrossRef]

44. Gil-Pérez, D.; Vilches, A. La comprensión e impulso de la Sostenibilidad: Un requisito Imprescindible para una acción educativa y ciudadana eficaz. Rev. Educ. Ambient. Sostenibilidad 2019, 1, 2101. [CrossRef] 
45. García-Díaz, E.; Fernández-Arroyo, J.; Rodríguez-Marín, F.; Puig-Gutiérrez, M. Más allá de la sostenibilidad: Por una Educación Ambiental que incremente la resiliencia de la población ante el decrecimiento. Rev. Educ. Ambient. Sostenibilidad $2019,1,1101$. [CrossRef]

46. Puig-Gutiérrez, M.; Cruz-Guzmán, M.; Rodríguez-Marín, F. Prospective early childhood teachers'difficulties in analysing children's ideas about the natural and social environment. S. Afr. J. Educ. 2019, 39, 1-10. [CrossRef]

47. Caeiro, S.; Azeiteiro, U.M. Sustainability Assessment in Higher Education Institutions. Sustainability 2020, 12, 3433. [CrossRef]

48. Niedlich, S.; Bauer, M.; Doneliene, M.; Jaeger, L.; Rieckmann, M.; Bormann, I. Assessment of Sustainability Governance in Higher Education Institutions-A Systemic Tool Using a Governance Equalizer. Sustainability 2020, 12, 1816. [CrossRef]

49. Roos, N.; Heinicke, X.; Guenther, E.; Guenther, T.W. The Role of Environmental Management Performance in Higher Education Institutions. Sustainability 2020, 12, 655. [CrossRef]

50. Caeiro, S.; Sandoval Hamón, L.A.; Martins, R.; Bayas Aldaz, C.E. Sustainability Assessment and Benchmarking in Higher Education Institutions-A Critical Reflection. Sustainability 2020, 12, 543. [CrossRef]

51. UNESCO. Roadmap for Implementing the Global Action Programme on Education for Sustainable Development; Ediciones Unesco: Paris, France, 2014. Available online: http:/ / unesdoc.Unesco.org/images/0023/002305/230514e.pdf (accessed on 20 November 2020).

52. UNESCO. Education for Sustainable Development Goals. Learning Objectives; Ediciones Unesco: Paris, France, 2017. Available online: https:/ / unesdoc.unesco.org/ark:/48223/pf0000252423 (accessed on 20 November 2020).

53. López, A.; Gutiérrez, J.; Poza, F. Sustainable management of pre-school education centers: A case study in the province of Granada. Procedia Soc. Behav. Sci. 2017, 237, 541-547. [CrossRef]

54. Perales-Palacios, F.J.; Burgos-Peredo, O.; Gutiérrez-Pérez, J. El programa Ecoescuelas: Una evaluación crítica de fortalezas y debilidades. Perf. Educ. 2014, 36, 98-119. [CrossRef]

55. Melis, C.; Wold, P.A.; Billing, A.M.; Bjørgen, K.; Moe, B. Kindergarten Children's Perception about the Ecological Roles of Living Organisms. Sustainability 2020, 12, 9565. [CrossRef]

56. Engdahl, I. Early Childhood Education for Sustainability: The OMEP World Project. IJEC 2015, 47, 347-366. [CrossRef]

57. Ärlemalm-Hagsér, E. Student Teachers' Workplace-Based Learning in Sweden on Early Childhood Education for Sustainability: Experiences in Practice Settings. IJEC 2017, 49, 411-427. [CrossRef]

58. Weldemariam, K.; Boyd, D.; Hirst, N.; Sageidet, B.M.; Browder, J.K.; Grogan, L.; Hughes, F. Critical Analysis of Concepts Associated with Sustainability in Early Childhood Curriculum Frameworks Across Five National Contexts. IJEC 2017, 49, 333-351. [CrossRef]

59. Davis, J.M.; Davis, J.E. Early childhood teacher education and education for sustainability. In Researching Early Childhood Education for Sustainability: Challenging Assumptions and Orthodoxies; Sue-Elliott, E.M., Ärlemalm-Hagsér, J.D., Eds.; Routledge: New York, NY, USA, 2020; p. 9.

60. UNESCO. Guidance for the Use of the OME. Environmental Rating Scale for Sustainable Development in Early Childhood (ERSSDEC). 2020. Available online: http:/ / www.eceresourcebank.org/index.php?hCode=SCALE_03_02 (accessed on 20 November 2020).

61. UNESCO. Shaping the Future We Want. UN Decade for Education for Sustainable Development (2005-2014); Final Report; UNESCO: Paris, France, 2014. Available online: http:/ / unesdoc.unesco.org/images/0023/002301/230171e.pdf (accessed on 20 November 2020).

62. Spiteri, J. Early Childhood Education for Sustainability. In Quality Education, Encyclopedia of the UN Sustainable Development Goals; Leal Filho, W., Azul, A.M., Brandli, L., Gökçin, P., Wall, T., Eds.; Springer Nature: Cham, Switzerland, 2020. [CrossRef]

63. Iyer-Raniga, U.; Myla-Andamon, M. Transformative learning: Innovating sustainability education in built environment. Int. J. Sustain. High. Educ. 2016, 17, 105-122. [CrossRef]

64. Ofei-Manu, P.; Didham, R.J. Identifying the factors for sustainability learning performance. J. Clean. Prod. 2018, 198, 1173-1184. [CrossRef]

65. Wiek, A.; Bernstein, M.; Foley, R.; Cohen, M.; Forrest, N.; Kuzdas, C.; Withycombe, L. Operationalising competences in higher education for sustainable development. In Handbook of Higher Education for Sustainable Development; Routledge: Abingdon, UK, 2015; pp. 241-260.

66. Marouli, C.; Misseyanni, A.; Papadopoulou, P.; Lytras, M.D. A New Vision for Higher Education: Lessons from Education for the Environment and Sustainability. In Active Learning Strategies in Higher Education. Teaching for Leadership, Innovation, and Creativity; Misseyanni, A., Lytras, M.D., Papadopoulou, P., Marouli, C., Eds.; Emerald Publishing Limited: Bingley, UK, 2018 ; pp. 361-388.

67. Murga-Menoyo, M.A.; Novo, M. Sostenibilidad, desarrollo "glocal”y ciudadanía planetaria. Referentes de una Pedagogía para el desarrollo sostenible. Teoría Educ. Rev. Interuniv. 2017, 29, 55-78. [CrossRef]

68. Poza-Vilches, F.; López-Alcarria, A.; Mazuecos-Ciarra, N. A professional competences' diagnosis in education for sustainability: A case study from the Standpoint of the Education Guidance Service (EGS) in the Spanish Context. Sustainability 2019, 11, 1568. [CrossRef]

69. Paujik, Y.M.; Miller, M.; Gibson, M.; Walsh, K. Doing'socio-political sustainability in early childhood: Teacher-as-researcher reflective practices. Glob. Stud. Child. 2020, 1-16. [CrossRef]

70. Ketlhoilwe, M.J. Environmental Education Policy Implementation Challenges in Botswana Schools. S. Afr. J. Environ. Educ. 2007, 24, 171-189.

71. Selzing-Musa, G.; Shwamut Ishaku, E.; Dakur Amos, W. Transforming early childhood education for sustainable development. J. Educ. Found. 2016, 6, 63-69. 
72. O'Brien, C.; Howard, P. (Eds.) Living Schools: Transforming Education; Education for Sustainable Well-Being Press: Winnipeg, MB, Canada, 2020.

73. Bissaco, C.M.; Machado-Da-Silva, D.; Dos Reis, D.A. Early Childhood Education, Environmental Education and Education in Values: A proposal for teacher training. Remea-Mag. Eletronica Mestr. Educ. Ambient. 2016, 33, 233-255.

74. Kim, S.; Dreamson, N. Culturally inclusive early childhood education for sustainability: A comparative document analysis between Australian and Korean curricula. Eur. Early Child. Educ. Res. J. 2020, 28, 712-730. [CrossRef]

75. Xie, S.; Li, H. Accessibility, affordability, accountability, sustainability and social justice of early childhood education in China: A case study of Shenzhen. Child. Youth Serv. Rev. 2020, 118, 105359. [CrossRef] [PubMed]

76. Tzima, S.; Styliaras, G.; Bassounas, A.; Tzima, M. Harnessing the potential of storytelling and mobile technology in intangible cultural heritage: A case study in early childhood education on sustainability. Sustainability 2020, 12, 9416. [CrossRef]

77. Bahtic, K.; Jevtic, A.V. Young children's conceptions of sustainability in Croatia. Int. J. Early Child. 2020, 52, 195-211. [CrossRef]

78. Ward, K. Creative Arts-Based Pedagogies in Early Childhood Education for Sustainability (Efs): Challenges and Possibilities Aust. J. Environ. Educ. 2013, 29, 165-181. [CrossRef]

79. Inoue, M.; O'Gorman, L.; Davis, J. Researching Early Childhood Teachers' Understanding and Practices of Education for Sustainability in Queensland: A Research Collaboration between Japan and Australia. Aust. J. Environ. Educ. 2016, 32, 174-191. [CrossRef]

80. Wilutzky, W. Emotions as pragmatic and epistemic actions. Front. Psychol. 2015, 6, 1593. [CrossRef]

81. Di Fabio, A.; Saklofske, D.H. The Contributions of Personality Traits and Emotional Intelligence to Intrapreneurial Self-Capital: Key Resources for Sustainability and Sustainable Development. Sustainability 2019, 11, 1240. [CrossRef]

82. Di Fabio, A. Positive Healthy Organizations: Promoting Well-Being, Meaningfulness, and Sustainability in Organizations. Front. Psychol. 2017, 8, 1938. [CrossRef]

83. Çakır Yıldırım, B.; Karaarslan Semiz, G. Future Teachers' Sustainable Water Consumption Behavior: A Test of the Value-BeliefNorm Theory. Sustainability 2019, 11, 1558.

84. Şebnem Feriver, G.; Teksöz, R.O.; Alan, R. Training early childhood teachers for sustainability: Towards a 'learning experience of a different kind'. Environ. Educ. Res. 2016, 22, 717-746. [CrossRef]

85. Gutiérrez- Pérez, J.; Pirrani, F. An integrated curricular program of environmental and health education in secondary school through an active science model with problem-based learning. Ensen. Cienc. Rev. Investig. Exp. Didact. 2009, 3114-3117. Available online: https:/ / www.raco.cat/index.php/Ensenanza/article/view/294616 (accessed on 8 January 2021).

86. Crinall, S.; Somerville, M. Informal environmental learning: The sustaining nature of daily child/water/dirt relations. Environ. Educ. Res. 2020, 26, 1313-1324. [CrossRef]

87. Bogusevschi, D.; Tal, I.; Bratu, M.; Gornea, B.; Caraman, D.; Ghergulescu, I.; Muntean, G.M. Water cycle in nature: Small-scale STEM education pilot. In Proceedings of the EdMedia: World Conference on Educational Media and Technology, Amsterdam, The Netherlands, 25 June 2018; Bastiaens, T., van Braak, J., Brown, M., Cantoni, L., Castro, M., Christensen, R., Davidson-Shivers, G., DePryck, K., Ebner, M., Fominykh, M., et al., Eds.; Association for the Advancement of Computing in Education (AACE): Waynesville, NC, USA, 2018; pp. 1496-1505. Available online: https://www.learntechlib.org/primary/p/184370/ (accessed on 8 January 2021).

88. Borreguero, G.M.; Correa, F.L.N.; Núñez, M.M.; Martín, J.S. Recreational experiences for teaching basic scientific concepts in primary education: The case of density and pressure. EURASIA J. Math. Sci. Technol. Educ. 2018, 14, em1616. [CrossRef]

89. Maddox, P.; Doran, C.; Williams, I.D.; Kus, M. The role generational influence in waste education programmes: The THAW project. Waste Manag. 2011, 31, 2590-2600. [CrossRef]

90. Perkins, J.H. Development of risk assessment for nuclear power: Insights from history. J. Environ. Stud. Sci. 2014, 4, $273-287$. [CrossRef]

91. López-Alcarria, A.; Gutiérrez-Pérez, J.; Rodríguez-Sabiote, C.; Poza-Vilches, F. The future is in childhood: Evaluation of the quality of sustainability programmes in the early years. SHS Web Conf. 2016, 26, 01044. [CrossRef]

92. Jie, C.Y.; Yi, L.L.; Yi-Chun, L. Effects of locus of control on behavioral intention and learning performance of energy knowledge in game-based learning. Environ. Educ. Res. 2017, 23, 886-899. [CrossRef]

93. Ouariachi, T.; Gutiérrez-Pérez, J.; Olvera-Lobo, M.D. Can serious games help to mitigate climate change? Exploring their influence on Spanish and American teenagers' attitudes. Psyecology 2018, 9, 365-395. [CrossRef]

94. Delors, J. La Educación Encierra un Tesoro; Santillana/Unesco: Madrid, Spain, 1997.

95. Leal, W.; Manolas, E.; Pace, P. The future we want: Key issues on sustainable development in higher education after Rio and the UN decade of education for sustainable development. Int. J. Sustain. High. Educ. 2015, 16, 112-129. [CrossRef]

96. Cebrián, G.; Junyent, M. Competencias profesionales en Educación para la Sostenibilidad: Un estudio exploratorio de la visión de futuros maestros. Enseñ. Cienc. 2014, 32, 29-49. [CrossRef]

97. Melendro, M.; Murga, M.Á.; Novo, M.; Bautista-Cerro, M.J. Estrategias formativas innovadoras en educación ambiental y para el desarrollo sostenible. RIED. Rev. Iberoam. Educ. Distancia 2008, 11, 15-39. [CrossRef]

98. Murga-Menoyo, M.A. Competencias para el desarrollo sostenible: Las capacidades, actitudes y valores meta de la educación en el marco de la Agenda global post-2015. Foro Educ. 2015, 13, 55-83. [CrossRef]

99. Leal, W.; Raath, S.; Lazzarini, B.; Vargas, V.R.; de Souza, L.; Anholon, R.; Quelhas, O.L.G.; Haddad, R.; Klavins, M.; Orlovic, V.L. The role of transformation in learning and education for sustainability. J. Clean. Prod. 2018, 199, 286-295. [CrossRef] 
100. Howlett, C.; Ferreira, J.; Blomfield, J. Teaching sustainable development in higher education. Int. J. Sustain. High. Educ. 2016, 173, 305-321. [CrossRef]

101. Ballard, H.L.; Belsky, J.M. Participatory action research and environmental learning: Implications for resilient forests and communities. Environ. Educ. Res. 2010, 16, 611-627. [CrossRef]

102. Long, J.W.; Ballard, H.L.; Fisher, L.A.; Belsky, J.M. Questions that won't go away in participatory research. Soc. Nat. Resour. 2016, 29, 250-263. [CrossRef]

103. Lewis, M.E. A teacher's schoolyard tale: Illuminating the vagaries of practicing participatory action research (par) pedagogy. Environ. Educ. Res. 2004, 10, 89-114. [CrossRef]

104. Raimondo, A.; Perales, F.J.; Gutiérrez, J. Formación y educación ambiental: Una experiencia integradora de aprendizaje basado en los problemas del territorio. Profr. Rev. Curric. Form. Profr. 2012, 16, 61-278.

105. Raimondo, A.; Perales, F.J.; Gutiérrez, J.; Vidoz, S. Educación-Acción: Herramientas para Afrontar la Injusticia Ambiental en una Comunidad Costera. Rev. Int. Educ. Justicia Soc. RIEJS 2018, 7, 95-117. [CrossRef]

106. Raimondo, A.; Monti, A.; Perales-Palacios, F.J.; Gutiérrez-Perez, J. Evaluation of an action-research project by university environmental volunteers. Int. Res. Geogr. Environ. Educ. 2017, 26, 54-70. [CrossRef]

107. Fazio, X.; Karrow, D. Negotiating the constraints of schools: Environmental education practices within a school district. Environ. Educ. Res. 2013, 19, 639-655. [CrossRef]

108. Cincera, J.; Boeve-de Pauw, J.; Simonova, P. Emancipatory or instrumental? Students' and teachers' perceptions of the implementation of the EcoSchool program. Environ. Educ. Res. 2019, 25, 1083-1104. [CrossRef]

109. Lindström, M.; Johmsson, P. Environmental Concern, Self-concept and Defence Style: A study of the Agenda 21 process in a Swedish municipality. Environ. Educ. Res. 2003, 9, 51-66. [CrossRef]

110. De Haan, G. The BLK '21' programme in Germany: A 'Gestaltungskompetenz'-based model for Education for Sustainable Development. Environ. Educ. Res. 2006, 12, 19-32. [CrossRef]

111. Elliot, J. Developing Community-Focused Environmental Education: Through Action Research Mimeograph; Centre for Applied Research in Education, School of Education, University of East Anglia: Norwich, UK, 1991.

112. Posch, P. Action research in environmental education. Educ. Action Res. 1993, 1, 447-455. [CrossRef]

113. Blasi Vélez, M.; Quesada, J.; Acale, L.; Chamorro, M.; Solozabal, A.; Vallejo, I.; Vico, T.; Fresco, Q. Viviendo el Barrio: Haciendo Escuela de 0 a 6 Años; Octaedro: Granada, Spain, 2008.

114. Gil, L.; Guzmán, M.; Moreno, E. Caminando Hacia la Escuela que Queremos; Octaedro: Barcelona, Spain, 2013.

115. Fundación Granada Educa. Available online: https://www.fundaciongranadaeduca.org/ (accessed on 20 November 2020).

116. Vasiliki, P. Professional Development of In-service Primary Teachers in Environmental Education: An action research approach. Environ. Educ. Res. 1995, 1, 85-97. [CrossRef]

117. Shallcross, T.; O'Loan, K.; Hui, D. Developing a School Focused Approach to Continuing Professional Development in Sustainability Education. Environ. Educ. Res. 2000, 6, 363-382. [CrossRef]

118. McDonnell, P.; McNiff, J. Action Research for Nurses; Sage: Thousand Oaks, CA, USA, 2016.

119. Lam, G. Connecting Theory, Knowledge, and Practice: A Review of Action Research. Qual. Rep. 2017, 22, 2357-2368. Available online: https:/ /nsuworks.nova.edu/tqr/vol22/iss9/6 (accessed on 20 November 2020).

120. MacNiff, J. You and Your Action Research Project; Routledge: Abigdon on Thames, UK, 2016.

121. Miles, M.B.; Huberman, A.M.; Saldaña, J. Qualitative Data Analysis: A Methods Sourcebook, 3rd ed.; Sage Publications: London, UK, 2014.

122. Bernard, H.R.; Ryan, G.W. Analyzing Qualitative Research; Sage: Thousand Oaks, CA, USA, 2010.

123. Ritchie, J.; Lewis, J.; Nicholls, C.M.; Ormston, R. (Eds.) Qualitative Research Practice: A Guide for Social Science Students and Researchers; Sage: Thousand Oaks, CA, USA, 2013; pp. 269-290.

124. Wood, P.; Smith, J. Investigar en educación. Conceptos básicos y metodología para desarrollar proyectos de investigación. Educ. Siglo XXI 2018, 36, 263-266.

125. Miles, M.B.; Huberman, A.M. Qualitative Data Analysis: An Expanded Sourcebook; Sage: London, UK, 1994. 